\title{
Wojciech Sztaba \\ Tło zmieszane z niczego. Problem nihilizmu u Witkacego
}

\begin{abstract}
Sztaba Wojciech, Tło zmieszane z niczego. Problem nihilizmu u Witkacego [A background created from nothing: The issue of nihilism in Witkacy's works]. „Przestrzenie Teorii" 21. Poznań 2014, Adam Mickiewicz University Press, pp. 247-297. ISBN 978-83-232-2740-3. ISSN 1644-6763.

As Witkacy wrote in Narcotics, it is "the surrounding nothingness which creates a negative background for all being" that makes things visible. Nihilism provides a framework for Witkacy's work. His philosophy and esthetics are a response to the nihilistic lack of meaning and the absolute, while his cultural pessimism is a projection of the lost paradise. The romantic attitude that he had developed by reading Schopenhauer and Nietzsche left deep traces in his art, thus generating the iconography of his paintings and permeating his dramas and novels.
\end{abstract}

\section{Czas marny}

W jednej z pierwszych manifestacji nihilizmu, w powieści William Lovell, Ludwik Tieck opisuje stan psychiczny człowieka, któremu umknął sens życia:

Pojęcie Czasu stało się dla mnie straszne. Gdy mam przed sobą dzień i nie wiem, co mam z nim począć - och, i do tego jeszcze perspektywa rozpościerającej się przede mną pustyni nudnych tygodni! A mimo to, w strachu przed myślą o śmierci, wyżebrać od Czasu godzinę i jeszcze godzinę życia. Jakże nędzny jest człowiek, że musi umrzeć, i jak bardzo byłby nieszczęśliwy, gdyby żył wiecznie. Jak szalonym i bezsensownym jest nasze życie przez te niekończące się sprzeczności!!

Czterdzieści lat później Georg Büchner powtarza ten opis katastrofy świadomości w Śmierci Dantona:

Danton: To bardzo nudne, zawsze ubierać najpierw koszulę, a potem na nią spodnie i wieczorem do łóżka, a rano znowu z niego wyłazić i zawsze jedną nogę

1 „Der Begriff von Zeit ist mir jetzt fürchterlich. Wenn ich einen Tag vor mir habe, ohne zu wissen, was ich mit ihm anfangen soll - oh, und dann den Blick über die leere Wüste von langweiligen Wochen hinaus! Und wieder eine Stunde nach der andern von der Zeit zu betteln, sich vor dem Gedanken des Todes zu entsetzen! Wie elend ist der Mensch, dass er sterben muss, und wie höchst unglückselig müsste er sein, wenn er ewig lebte! Wie toll und unsinnig ist unser Leben durch diese unaufhörlichen Widersprüche!” (L. Tieck, William Lovell, 1795, rozdział 59, list 13). 
przed drugą stawiać; nic na to nie wskazuje, żeby miało być inaczej. To bardzo smutne, i to, że miliony już tak robiły, i miliony tak będą robić, i że jeszcze na dodatek składamy się z dwóch połówek, które to samo robią, więc wszystko zdarza się podwójnie - to bardzo smutne ${ }^{2}$.

U Witkacego znaleźć można wiele wariacji tego tematu. W Pragmatystach brzmi on tak:

Plasfodor: Ta piekielna banalność istnienia. Jest godzina czwarta po południu. Potem będzie kolacja, potem orgia, potem seans, potem nocne koszmary, potem zwykła porcja środków wzmacniających. Och! To nie do wytrzymania.

Dziesięć lat później mówi Sajetan w Szewcach: „a tu wlecze się ta gówniarska kiełbasa bez końca, aż za szary, nudny, jałowcowo-nieśmiertelnikowy horyzont beznadziejnego jałowego dnia, gdzie czeka wszawa zatęchła śmierć"3.

Nihilizm należy do porządku symbolicznego, do nadbudowy, do literatury ${ }^{4}$ Zanim stanie się tematem prac seminaryjnych, objawia się jako ostre zapalenie świadomości rozglądającej się po wyobrażonych ruinach świata zniszczonego nie przez kataklizm czy wojnę, lecz przez utratę spoiwa, które miało podtrzymywać jego kosmiczną architekturę. Jest to stan ciężki, kończący się czasem chorobą psychiczną lub śmiercią. Lista dotkniętych nihilizmem jest długa: Kleist, Hölderlin, Nietzsche, Dostojewski, Strindberg, Witkacy...

Nihilizm to dom duchów, w którym nawiedzeni są własnymi egzorcystami: $\mathrm{w}$ pokojach straszą wiszące na ścianach makatki $\mathrm{z}$ arcydziełami sztuki, na regałach pleśnieją tomy budujących lektur, obiecujących świat urządzony, jasny i mądry, a za oknem - „nowy, wspaniały świat”.

2 Danton: Das ist sehr langweilig, immer das Hemd zuerst und dann die Hosen drüber zu ziehen und des Abends ins Bett und morgens wieder herauszukriechen und einen $\mathrm{Fu}$ immer so vor den andern zu setzen; da ist gar kein Absehen, wie es anders werden soll. Das ist sehr traurig, und daß Millionen es schon so gemacht haben, und daß Millionen es wieder so machen werden, und daß wir noch obendrein aus zwei Hälften bestehen, die beide das nämliche tun, so daß alles doppelt geschieht - das ist sehr traurig (G. Büchner, Dantons Tod (1835), akt II, scena I).

3 S.I. Witkiewicz, Dramaty, t. I-III, oprac. J. Degler, Warszawa 1996-2004 (Dzieła zebrane, t. 5-7), t. I, s. 185, t. III, s. 322.

${ }^{4}$ Nihilizm jest pojęciem niejasnym, kłopotliwym, oscyluje między różnymi sposobami jego stosowania. Wyraża to, czego nie ma, czego brak: brak sensu i daremność życia, niemożność poznania, brak moralnych wartości, ale jednocześnie może być okazją do wielkiego „przemeblowania”, do generalnego remanentu w katalogu wartości. Na temat pojęcia nihilizmu zob. M. Werner, Wobec nihilizmu. Gombrowicz. Witkacy, Warszawa 2009. 
Wszystko na nic, wszystko na darmo, tylko złuda, ogłaszają nawiedzeni. „Mam uczucie, jakby w głowie mojej była talia kart, ułożona do jakiejś potwornej, fałszywej gry”, mówi Karnak w Normalnym człowieku ${ }^{5}$.

\section{Heinrich von Kleist:}

Nie potrafimy zdecydować, czy to, co nazywamy prawdą, jest naprawdę prawdą, czy tylko nam się tak wydaje. Straciłem swój jedyny, najwyższy cel, i nie mam innego - wewnętrzny wstręt opanowuje moją wolę .

\section{Friedrich Hölderlin:}

Kiedy wniknę w sens życia, cóż ostatecznie $\mathrm{z}$ niego pozostaje? Nic. Kiedy się wznoszę duchem, cóż jest wyższe ponad wszystko? Nic. [...] na wskroś opętani przez Nicość, która nami rządzi, tak do głębi przekonani, że urodziliśmy się dla tej Nicości, że Nicość kochamy, wierzymy w nią i zapracowujemy się dla niej, by powoli przejść w Nicość 7 .

\section{Karoline von Günderrode:}

A teraz jest wszystko inaczej/Niebo się zawaliło, przepaść zapełniona/I przykryta rozumem, bardzo wygodnie po niej chodzicí8 .

\section{Georg Büchner:}

Wszystko stało się niczym i małe, od czasu, kiedy nie ma Boga [...] Szukał czegoś, jak zgubionych snów, ale nic nie znalazł. [...] Świat, z którego chciał korzystać, miał potworne pęknięcie. Nie było w nim nienawiści ani miłości, ani nadziei, tylko straszliwa pustka i ten dręczący niepokój, by ją zapełnić.

Okropna myśl przychodzi mi do głowy, wydaje mi się, że wśród ludzi są nieszczęśliwi, i to nieuleczalnie, tylko z tego powodu, że są9 .

\section{Giacomo Leopardi:}

Życie to gorycz i nuda, poza tym nic ${ }^{10}$.

${ }^{5}$ S.I. Witkiewicz, Dramaty, t. III, s. 483.

${ }^{6}$ Heinrich von Kleist, w liście z 22.03.1801, <http://www.kleistdaten.de/index.php? title=Brief_1801-03-22>.

${ }^{7}$ F. Hölderlin, Hyperion, [w:] tenże, Pod brzemieniem mego losu, przełożyły i opracowały A. Milska, W. Markowska, Warszawa 1976, s. 326.

${ }^{8}$ K. von Günderrode, Vorzeit und neue Zeit, [w:] taż, Gesammelte Werke. Band 1-3, Band 3, Berlin-Wilmersdorf 1920-1922, s. 16 („Doch alles ist ganz anders jetzt geworden,/Der Himmel ist gestürzt, der Abgrund ausgefüllt,/Und mit Vernunft bedeckt, und sehr bequem zum gehen").

${ }^{9}$ G. Büchner, Lenz (1835-1839), [w:] Sämtliche Werke und Briefe, Leipzig 1922, s. 104; Leonce und Lena (1813-1837), [w:] Sämtliche Werke und Briefe, s. 131.

10 G. Leopardi, I Canti, XXVIII, A se stesso (1836). 


\section{Friedrich Nietzsche:}

Nihilizm stoi przed drzwiami, ten najbardziej niepożądany ze wszystkich gości. Nihilizm: brak celu, brak odpowiedzi na „dlaczego?”. Co znaczy nihilizm? - że najwyższe wartości są odwartościowane.

Ziemia stała się małą i podskakuje na niej ostatni człowiek, który wszystko rozdrabnia.

Trzeba mieć chaos w sobie, aby narodzić gwiazdę.

Nie ma pesymistycznej sztuki. Sztuka potwierdza. Hiob potwierdza ${ }^{11}$.

\section{Tadeusz Miciński:}

Niech będą pochwalone nocne godziny,

Kiedy człowiek jest sam

w otchłani strachu i męczarni,

kiedy poznaje piekło swego istnienia,

i jak Demon - zamyśla się

nad światem, w którym musi zginąć!

Umysł mi się plącze,

Boga nie ma, to wiemy już $\dot{z}^{12}$.

\section{Roman Jaworski:}

Istnienia naszego nijak pojąć nie możemy. Noc nas tylko ogarnia i zimne milczenie. Cóż więc czynić należy? ${ }^{13}$

\section{Jan Kasprowicz:}

Bo strach już pomyśleć, już człowiek

Niemal obłędu jest blisko,

Że się lat setki tysięcy

Powtarza to widowisko... ${ }^{14}$

\section{Martin Heidegger:}

Dlaczego w ogóle jest raczej byt niźli Nic?15

\section{Tristan Tzara:}

DADA ZNACZY NIC ${ }^{16}$.

Ileż to razy czytano te zdania?

11 F. Nietzsche, Sämtliche Werke, Kritische Studienausgabe in 15 Bänden, MünchenBerlin-New York 1980, t. 12, s. 350; t. 4, s. 17, 19; t. 13, s. 241.

12 T. Miciński, W mrokach Złotego Pałacu czyli Bazylissa Teofanu (1905), wybór i opracowanie T. Wróblewska, Kraków 1978, s. 128, 410.

13 R. Jaworski, Historie maniaków (1910), Kraków 1978, s. 86.

14 J. Kasprowicz, Księga ubogich, pieśń XIII (1916), Warszawa 1934, s. 41.

15 M. Heidegger, Czym jest metafizyka (wykład wygłoszony 24 lipca 1929 we Freiburgu), przeł. K. Pomian, [w:] Budować, mieszkać, myśleć. Eseje wybrane, wybrał i opracował K. Michalski, Warszawa 1977, s. 47.

16 T. Tzara, Manifest Dada 1918, „La revue Dada 3”, Zürich 1918. 
„To jest, ale równie dobrze mogłoby tego nie być wcale, mogłoby nie być mnie, nie być nic" mówi Atanazy w Pożegnaniu jesieni17. Ze świadomością, że mogłoby być „nic”, żyje się, myśli i tworzy - inaczej. Nicość jest tematem Witkacego, a może nawet - głównym tematem. Deklinuje ją na różne sposoby, pod różnymi postaciami: nuda, pustka, rozpacz, przerażenie, bezsens, świat na opak, upadek, perwersja, nienasycenie... Już przed laty zwrócił na to uwagę Lech Sokół, pisząc w pracy o Szewcach o jednej z głównych figur nihilizmu, o nudzie ${ }^{18}$. Nuda jest, według Schopenhauera, doznaniem daremności, bezsensu: najpierw czegoś chcemy, pożądamy, a kiedy się to pragnienie spełnia, pojawia się nic, rozczarowanie, nuda, i znowu pożądanie, i tak w kółko... Witkacy nazywa ten stan nienasyceniem.

Nihilizm nadaje kontur całej twórczości Witkacego, od filozofii po „teatr w życiu”. Na tle „otaczającej nicości, która stanowi jakby tło negatywne wszystkich istnień, jak przestrzeń międzygwiezdna stanowi rodzaj podkładu dla istnienia gwiazd, planet, komet i naszych własnych ciał"19, rzeczy stają się dopiero zauważalne. Jego filozofia i estetyka odpowiadają na nihilistyczny brak sensu i absolutu, jego katastrofizm to ciaggła projekcja raju utraconego, wspomnienie czasów „metafizycznych pępków”. Zaś ślady nihilizmu w jego sztuce to nie tylko poszczególne motywy, ikonografia, teksty, wypowiedzi - ale siła, która „trzyma” jego sztukę, przenika wszystkie opowiadane historie.

„Wobec nihilizmu” - określenie, które Mateusz Werner użył jako tytuł dla książki o Gombrowiczu i Witkacym - znaczy: obserwując z niepokojem, z boku, z brzegu, z drugiej strony ulicy, spektakl wykraczający poza ludzką miarę 20 . Bycie „wobec" pozwala na poczucie względnego bezpieczeństwa podczas oglądania z brzegu szalejącego żywiołu; zwykło nazywać się za Kantem ten stan obserwatora „wzniosłością”. Tylko będąc „wobec”, można katastrofę opisywać, bo w środku, w samym centrum, pewnie nie widzi się nic. Z brzegu widać jej niszczącą siłę, Eros i Tanatos w jednym, bezgraniczny egoizm, zwycięstwo mocnych nad słabymi, demonstrację zła, któremu nie grożą żadne zaświaty.

17 S.I. Witkiewicz, Pożegnanie jesieni, Kraków 2004, s. 76.

18 L. Sokół, Zagadnienie nudy w „Szewcach” Witkacego, „Pamiętnik Literacki” 2002, r. XCIII, z. 4.

19 S.I. Witkiewicz, Narkotyki - Niemyte dusze, wstępem poprzedziła i opracowała A. Micińska, Warszawa 1975, s. 221.

$20 \mathrm{M}$. Werner, Wobec nihilizmu... 
Witkacy obserwuje i opisuje to, co się dzieje w duszy człowieka nawiedzonego przez nihilizm, żyjącego w świecie bez celu, bez wartości zakotwiczonych $\mathrm{w}$ zaświatach, świecie pogrążonym w nudzie. Akcja jego powieści i dramatów odbywa się w „czasie marnym”, który niekiedy możemy umiejscowić na podstawie ukrytych w tekście aluzji około końca XX wieku, czyli w niedalekiej przyszłości autora. Realia i dekoracje wzięte są albo z Polski, albo z tropików, ale w gruncie rzeczy przypominają miejsce panowania króla Ubu: „Rzecz dzieje się w Polsce, czyli nigdzie”. Wynajduje dla nihilistycznej wizji mocne obrazy, które łączą, jak w teatrze Grand Guignol, horror z groteską; nie ustępują one ostrością dużo późniejszym scenom z „końca czasu”, znanym z filmów przedstawiających rozpad cywilizacji: Fahrenheit 451 Truffauta, Alphaville Godarda, Clockwork Orange Kubricka, Blade Runner Scotta czy Brazil Gilliama.

W Witkacowskiej antyutopii wszystko, co najcenniejsze - Tajemnica Istnienia, przeżycie metafizyczne, sztuka - należy już do historii, wspominanej tylko przez nielicznych. Sztuka w jej istotnej formie staje się czymś nieznanym, zbędnym, przeszkadzającym, zastępuje ją „bezpośrednia twórczość w życiu", komponująca podniecające na moment intrygi, zawiłe kombinacje uczuć i towarzyskich stosunków ${ }^{21}$.

Współczesna krytyka zarzucała Witkacemu nihilizm. „Jestem nihilistycznym burżujem", cytował głos z prasy po przedstawieniu Pragmatystów ${ }^{22}$. Lecz rodzajów nihilistów, jak i nihilizmów jest wiele, czego przeciwnicy Witkacego nie dostrzegali. Nieliczni sojusznicy, nawet przejściowi, mieli więcej zrozumienia. W redakcyjnym wstępie do opublikowanych w „Zdroju” w 1920 roku Pragmatystów czytamy:

Wspólny bowiem punkt wyjścia Witkiewicza i nasz. Patrzymy w świat, wyzbyty wszelkiej wiary metafizycznej, w Sztukę, która swe sedno zatraciła, w orgie wojenne, rewolucyjne i ornamentacyjno-dźwiękowe materialistycznych, ku zgubie pędzących zmysłów. [...] pesymizm owłada Witkiewiczem. Widzi zło, lecz lekarstwa nie widzi. [...] Nie, żeby zło epoki podzielał. Jeno brak mu wiary, by się mu przeciwstawić. [...] twory Witkiewicza są (naszym zdaniem) dokumentem czasu, skamieniałością tak potwornie zbolałą i bijącą w niebo cierpieniem, zrodzonym z podłości XX wieku, że czas, by stały się wiecznie godnym szacunku i współ-uczucia krzykiem wołającego na puszczy 23 .

${ }^{21} \mathrm{Na}$ to, że tworzenie sztuki w życiu w systemie Witkacego ma konotację negatywną, zwrócił już uwagę Lech Sokół (Witkacy i Strindberg: dalecy i bliscy, Wrocław 1995, s. 352, 362). To istotna uwaga wskazująca na konieczność „zróżniczkowania” problemu sztuki i życia - właśnie u Witkacego, tak chętnie inscenizującego swój „teatr w życiu”.

22 J. Degler, Nota wydawnicza do dramatów, [w:] S.I. Witkiewicz, Dramaty, t. I, s. 597,599 .

23 Tamże, s. 601. 
Już wtedy więc zauważono, że „wobec Nicości” znaczy zarazem „przeciw Nicości”. Tym znaczeniem kierowali się Ewa Franczak i Stefan Okołowicz, tytułując album z fotografiami Witkacego Przeciw nicości (Kraków 1986). W jego powieściach, dramatach i obrazach ukrywają się moralitety, psychomachie, alegoryczne utwory z figurami walczących ze sobą cnót i grzechów - mają ostrzegać, przestraszać, potrząsać. Tylko, że cnót już także brak, pozostają we wspomnieniu i w domyśle.

*

Nie potrafimy sobie dzisiaj wyobrazić, jak mocno przed 200 laty przeżywali myśl o świecie bez Absolutu, bez sensu romantycy, pierwsi tego stanu kronikarze ${ }^{24}$, i jak przed 100 laty doświadczał go Witkacy; dzisiejsza opowieść nihilizmu stała się inna, „light”, sproblematyzowana, polityczna, na skalę globalną, a nie kosmiczną. Przywykliśmy radzić sobie ze świadomością, że poza tym, co jest, niczego nie ma. A to, co jest, tego mogłoby nie być.

Jak dochodzi się do nihilizmu? Jeśli nie przez własne doświadczenie, to poprzez towarzyszące życiu i komentujące je idee oraz poglądy, usłyszane lub przeczytane. Te wiadomości drążą umysł, tworzą raster światopoglądu, namiastkę wiary, nastawienie, apercepcję. Potęga memów jest wielka.

Nie inaczej widział świat młody Witkiewicz: jako własne o nim wyobrażenie. W liście do Heleny Czerwijowskiej przyznaje, że życie: „... staje się coraz podobniejsze do prawdy mojego o nim myślenia"25.

Nie przeżył nihilistycznej katastrofy tak jak romantycy, którzy nagle odkryli totalną pustkę, jak Tieck, Kleist, Hölderlin czy Jean Paul, który opisał wizję Chrystusa głoszącego, że nie ma Boga. Przeczytał o nihilizmie u Schopenhauera i u Nietzschego, znalazł w tych „lekturach obowiązkowych" dla młodych dekadentów listę i wykład atrybutów nihilizmu - nicość, śmierć Boga, brak wartości. Pewnie też czytał książki walczącego z nihilizmem księdza Dębickiego, które znajdowały się w czytelni zakopiańskiej, szczególnie Wielkie bankructwo umysłowe, gdzie znaleźć mógł przegląd pozycji filozoficznych sceptycyzmu, materializmu, solipsyzmu i nihilizmu. Jedyną radą na nihilizm jest wedle Dębickiego powrót

${ }_{24}$ B. Hillebrand, Ästhetik des Nihilismus: von der Romantik zum Modernismus, Stuttgart 1991. Praca szczególnie istotna, naświetlająca problem nihilizmu w kontekście filozofii, literatury i sztuki, począwszy od romantyzmu. Rozwinięciem pewnych wątków, również istotnych dla twórczości Witkacego, jest jego kolejna książka: B. Hillebrand, Ästhetik des Augenblicks, Göttingen 1999.

25 Listy Stanisława Ignacego Witkiewicza do Heleny Czerwijowskiej, podała do druku, opracowała i przypisami opatrzyła B. Danek-Wojnowska, „Twórczość” 1971, nr 9, s. 13-19. 
do zasad chrześcijaństwa: „... aby bojaźń Boga i nadzieja szczęścia za grobem przejmowała samowiedzę ludów i aby młodzież była wychowywana w zasadach religijnych" 26 . To przypomina, o jaką stawkę chodziło w tej dyskusji.

\section{Co to była za siła?}

Stanisław Witkiewicz ojciec, będąc w wieku, w którym jego syn spotkał się z problemem nihilizmu, również szukał odpowiedzi na pytania o sens sztuki i świata i znalazł je w pismach Hipolita Taine’a, opisującego rzeczowo, na wzór metod nauk przyrodniczych i bez powoływania się na idealistyczne cele, co to jest sztuka, od czego zależy jej kształt, wartość i dzieje. Gdy ta pozytywistyczna teoria przestała mu wystarczać, zwrócił się, jak wielu rozczarowanych wolnomyślicieli, do duchowości, którą, wedle przedstawicieli przeciwnego obozu, przepojona powinna być sztuka. Oparcie znalazł w tekstach brata Alberta, czyli Adama Chmielowskiego, towarzysza-malarza z czasów studiów w Monachium, orędownika duchowości sztuki, „wyrazu duszy ludzkiej”, jak będzie kpić Witkacy27.

$\mathrm{Na}$ początku roku 1912, w niezachowanym liście, Witkiewicz junior powiadamiał ojca o ważnym dla siebie wydarzeniu, o czym dowiadujemy się pośrednio z odwrotną pocztą, z pytania, które $\mathrm{w}$ liście $\mathrm{z}$ lutego tego roku Witkiewicz ojciec zadaje synowi: „Jaką jest ta kierownicza idea, która ujmuje w całość ścisłą wszystkie rozbieżne władze i poruszenia twej duszy?”28. Pytanie było z pewnością powtórzeniem słów syna, „kierownicza idea" przypomina jeden $\mathrm{z}$ głównych terminów teorii Taine’a, którą ojciec porzucił, a syn w niej jednak coś znalazł.

W pisanej w latach 1910-1911 powieści 622 upadki Bunga jest mowa o trudnej do wyrażenia transcendentnej idei jedności bytu. Cokolwiek by to miało być - nie chodziło z pewnością o abstrakcję, a o coś, co nadaje sens istnieniu. Choć Bungo „czuł bezwzględną nicość wszelkich wysiłków w kierunku wyrażenia jedności bytu", z drugiej strony uważał za możliwe obcowanie z tą ideą poprzez sztukę, bowiem jest ona „istnieniem bez zaprzeczenia, objawem absolutnej jedności bytu w czystej formie"29. Uzu-

${ }^{26}$ Ks. W.M. Dębicki, Wielkie bankructwo umysłowe. Rzecz o nowoczesnym skrajnym sceptycyzmie naukowo-filozoficznym. Z dodaniem studium: „Koniec wieku XIX-go pod względem umysłowym”. Charakterystyka znamion szczególnych, Warszawa 1895, s. 215-236.

${ }^{27}$ S.I. Witkiewicz, Jedyne wyjście, oprac. T. Jodełka-Burzecki, Warszawa 1968, s. 106.

28 S. Witkiewicz, Listy do syna, oprac. B. Danek-Wojnowska, A. Micińska, Warszawa 1969, s. 542.

${ }^{29}$ S.I. Witkiewicz, 622 upadki Bunga, czyli demoniczna kobieta, wstępem poprzedziła i opracowała A. Micińska, Warszawa 1974, s. 141, 123. 
pełnia tę myśl notatka z 21 sierpnia 1912 roku w dzienniku Bronisława Malinowskiego o koncepcji przyjaciela: „Sztuka jako odbicie metafizycznej istoty świata" 30 . Te nie całkiem sprecyzowane myśli nabierają konturu w kontekście jego najistotniejszej wtedy lektury: dzieł Schopenhauera (szczególnie Parerga und Paralipomena), gdzie mowa o zasadzie świata („Princip der Welt”) zawierającej skończoność, przemijalność, czasowość i zarazem nieskończoność, wieczność. Prace te, znane Witkacemu wobec braku tłumaczeń w oryginale, były w tym czasie w Polsce czytane, komentowane i miały znaczny wpływ tak na teorię, jak i sztukę. Miriam, Przybyszewski, Matuszewski, Irzykowski, Lange, Abramowski, Żuławski należeli do twórców i myślicieli, dla których myśli Schopenhauera były istotne ${ }^{31}$.

W młodości Witkacy zajmował się równie intensywnie filozofią, co malarstwem, choć listy ojca do syna przedstawiają zgoła inny obraz młodego artysty poświęcającego się głównie malowaniu studiów z natury. A przecież w tym czasie czytał poza Schopenhauerem także Kanta, Nietzschego, Macha, Avenariusa, Blondela, wkrótce Corneliusa i pewnie też wspominane później filozoficzne kompendia Boiraca i Ueberwega. Pierwsze próby filozoficzne syna skwitował Witkiewicz nieco ironicznie: ,jesteś autorem «systemaciku» metafizycznego"32. Z nieufnością obserwował jego późniejsze zainteresowania $\mathrm{w}$ tym kierunku, aprobując jedynie zamiar napisania teorii sztuki ${ }^{33}$.

„Systemacik” metafizyczny to pochodzące z lat 1902-1903 Marzenia improduktywa ${ }^{34}$ (cały rozdział poświęcił omówieniu filozofii Schopenhauera), dopełnione tekstem $O$ dualizmie. Musiał uważać te prace za

30 B. Malinowski, Dziennik w ścistym znaczeniu tego wyrazu, oprac. G. Kubica, Kraków 2002, s. 178.

31 J. Tuczyński, Schopenhauer a Młoda Polska, Gdańsk 1987 (1969), s. 139-159. Tu również w aneksie znajduje się przedruk rozdziału o Schopenhauerze z Marzeń improduktywa Witkacego.

32 S. Witkiewicz, Listy do syna, s. 165.

33 Tamże, s. 349.

${ }^{34}$ S.I. Witkiewicz, Marzenia improduktywa (1903), [w:] tenże, Pisma filozoficzne i estetyczne, t. 3: O idealizmie i realizmie, zebrał, opracował i przypisami opatrzył B. Michalski, Warszawa 1977. Tytuł pracy jest wieloznaczny. Może być ironicznym komentarzem do niejasnej sytuacji zawodowej młodego autora, może znaczyć jednak „rozważania filozofa”, marzenia, będące aluzją do Schopenhauerowskiego „wyobrażenia”, zaś improduktywizm odmową udziału w skompromitowanym systemie społecznym. W powieści Carla Einsteina, Bebuquin, pisanej krótko przed pierwszą powieścią Witkacego, czytamy: „Panie, który dałeś nam pracę, oszczędź mi jej, bym przeczuł możliwą wielkość, miast czynić małą miarkę". C. Einstein, Bebuquin oder de Dilletanten des Wunders (pisane 1906/1909; wydane w „Die Aktion”, 1912); tu w: Werke, Band I, 1908-1918, wydane przez Rolf-Peter Baacke, Berlin 1980, s. 99. 
udane, skoro je powielił, zachowały się dwa egzemplarze, zapewne z większego nakładu. Te pierwsze teksty filozoficzne to nie tylko popis erudycji zdolnego maturzysty, lecz samodzielna próba uporządkowania myśli i opisania, poprzez introspekcję, świadomości bycia $\mathrm{w}$ sobie i w świecie. Dla młodego człowieka nie ma chyba istotniejszej sprawy w filozofii, jak szukając odpowiedzi na sens istnienia, napotkać na pierwszy wysoki próg poznania: na nieuchwytność myśli i odczucia. Co to za miejsce, w którym odbywa się „widzenie” świata? Obecność w tekście rozdziału o Bogu i niemożliwości jego „osobowego istnienia” jest bardzo znacząca, wskazuje na kontekst, w jakim ta introspekcja się dokonuje - bez oparcia w transcendentnej „sile wyższej”, bez „obietnicy szczęścia za grobem".

W opisie Witkacego istnienie manifestuje się jako wydarzenie dramatyczne, którego retoryka nada ton i jego późniejszej twórczości. „Ja” zanurzone jest w nicości, w pustce, w bezdennej otchłani. Najpierw jest tylko nieuchwytnym uczuciem - „uczucie w swojej najczystszej, podmiotowej formie jest niczym" 35 . To ,ja" nie jest po prostu dane, lecz wynurza się z nicości, staje się, określa w „oscylacji”, w ciągłym przechodzeniu między odczuciem a intelektem, podmiotem a przedmiotem, syntezą i analiza, tymi dwoma stanami czy „kierunkami” jaźni.

Dopiero kiedy „wewnętrzny obserwator” rozpoczyna analizę pierwotnie nieokreślonego stanu istnienia, wtedy ,ja" zaczyna swoje świadome istnienie. Istnieć, znaczy być tego świadomym, wiedzieć o czasowości, przestrzenności, przyczynowych uwarunkowaniach. Tym samym jednak, przez „myślę, więc jestem”, znika uczucie nieskończoności, bezczasowości, znika owa niejasna, tajemnicza forma istnienia, dostępna jakoś w uczuciu, ale nie w analizie, przez którą „obserwator” spodziewał się ją uchwycić. Uczucie zostaje przetłumaczone na pojęcia i słowa, dalekie od oryginału, pozostawiając obserwatora $\mathrm{z}$ przeświadczeniem o niewyrażonej reszcie. Istnienie oparte na analizie, na obserwacji faktów i procesów wypiera „inne” istnienie, zawierające się w uczuciu, niedające się zanalizować, lecz odczuć, jest to „ja” nieobserwowane przez obserwatora.

W oscylacji między tymi stanami ,ja” szuka swojej prawdziwej postaci, jedności bytu. Nadaremnie, gdyż przepaść między nimi to „bez końca i bez nadziei” zasypywana „otchłań bez dna” 36 . „W tym leży niemożliwość wszelkiego poznania i tragedia każdego bytu”, kończy patetycznie Witkacy, wskazując na dramatyczny węzeł istnienia. Nie chodziło mu przecież o rozwiązanie naukowego problemu, ale o dochodzenie sensu życia. Jedyną możliwość przezwyciężenia, choć na moment, tej sprzeczności daje

35 S.I. Witkiewicz, Marzenia improduktywa, s. 24.

36 Tamże, s. 19. 
metafizyka i sztuka. Metafizyka poprzez opis „tych rzadkich chwil umysłu ludzkiego, gdy oświetlony jakąś wewnętrzną błyskawicą, widzi całą otchłań nieznanego, które go otacza i które tkwi w nim samym. Jest to najdalsze spojrzenie $\mathrm{w}$ nieświadomość, niedające nic konkretnego oprócz pustki”37. A sztuka przez to, że tę błyskawicę potrafi ściągnąć do obrazu.

Nie światłość, a ciemność jest atrybutem nieskończoności w minitraktacie Witkiewicza. Jedyne, co jaźń może w sobie zobaczyć, to otchłań, która oczekuje, wręcz domaga się zapełnienia i zmusza umysł, by nazywał, tłumaczył, usprawiedliwiał i obserwował siebie w lustrzanej galerii, bez końca. „... potrzask zwykły, z niczego”, można by powiedzieć za Gombrowiczem, z akcentem na „nic”.

Mijamy, nie wiedząc o sobie nic: cierpiące albo głupio szczęśliwe fantomy, pusząc się naszym nędznym (a mimo to jedynym dla całego bytu) aparacikiem pojęć, który czymże jest wobec nieprzejrzanych przestrzeni niewiadomego w nas i poza nami, niewyrażalnego w psychologistycznym i fizycznym poglądzie, i w obu razem ujętych w metafizyczny system,

pisał Witkacy po latach w Pożegnaniu jesieni ${ }^{38}$.

Dramat ,ja” opisany w Marzeniach improduktywa podzielił w powieści o 622 upadkach Bunga na cztery role: rolą Bunga jest próba połączenia obu stanów jaźni, uczucia i analizy w metafizycznym błysku, co ma miejsce i w sztuce, i w erotyzmie; baron Brummel gra „obserwatora”, analityka mnożącego w sobie punkty obserwacji swojej psychiki; książę Nevermore próbuje dyscypliną, pragmatyką podporządkować sobie sferę uczuć, zaś rolą Tymbeusza jest przypominanie o ciągle obecnej otchłani, o nicości otaczającej każde istnienie. Tę psychomachię opowiadać będzie Witkacy, ze zmianami, wariacjami i w różnej obsadzie, przez całe życie.

W Marzeniach improduktywa zwraca uwagę wybite w tekście zdanie 18-letniego autora: „Jeżeli coś istnieje, to tym samym zaprzecza temu principium, według którego istnieje" 39 . Zdanie brzmi jak zagadka.

Co znaczy? Witkacy podpowiada: „Zdanie to zawiera w sobie pojęcie dualizmu i oscylacji, które [...] są skonstatowaniem, że nic nie jest stałe i jednolite, lecz wszystko jest wahaniem między dwoma przeciwnościami”. Czyli to, co jest, nie daje się ująć, uchwycić jako coś stałego. Opisując istnienie, „trzeba się wyrzec już u podstawy wszelkiego określenia pozytywnego [...] Określenie pozostaje zawsze negatywnym", jest określeniem czegoś, przez to, czym nie jest. Tę zasadę często stosują artyści podczas

37 Tamże, s. 22.

38 S.I. Witkiewicz, Pożegnanie jesieni, s. 211.

39 Tenże, Marzenia improduktywa, s. 19. 
studiów z natury, kiedy rysują nie kontur przedmiotu, lecz granicę otaczającej go przestrzeni, czyli przestrzeni negatywnej; w ten sposób, jak dowodzi praktyka, najtrafniej oddać można kształt rzeczy.

Zdanie zapisane w 1903 roku pojawi się i w późniejszych tekstach jako znak ciągłości myśli dojrzałego już filozofa z przemyśleniami z młodości. Zwięźlej sformułowane, powtarza je Bungo: „Wszystko, co istnieje, zaprzecza tej zasadzie, według której istnieje". Tym razem zasada zostaje w innym miejscu tekstu nazwana, choć nie wyjaśniona: jest nią „transcendentna jedność" 40 . Wystąpi też w jego pierwszej sztuce teatralnej Maciej Korbowa i Bellatrix (1918): „Wszystko, co istnieje, zaprzecza temu principium, według którego istnieje. Oto ostatnie słowo metafizyki”, mówi Teozoforyk nad ciałem zabitej córki i w oczekiwaniu na własną śmierć. Poprzedza je innym zdaniem: „Wierzę, że żyć po śmierci [...] jest co najmniej dysonansem"41.

Nową wersję przynosi Jedyne wyjście (1930-1933). Transcendentna jedność nazywa się teraz ,jedność w wielości”, która jest najistotniejszym „principium istnienia”: „Jedność w wielości (czy wielość w jedności) jest pojęciem pseudosprzecznym, w którym staramy się ująć w krótkości potworną tajemnicę indywidualnego bytu oraz nieskończoności Istnienia poza nim”. I kilka stron później, jeszcze wyraźniej:

całe Istnienie w metafizycznym sensie nosi w sobie zabójczą sprzeczność (jedność w wielości) - zaprzeczania każdą chwilą swej najgłębszej istocie, tak i samo życie [...] niańczy w swoich wątpiach [...] jad wzniosłego, bo absolutnie koniecznego samobójstwa. Poprzez to żyć na wylot, tak jak śmiać się przez łzy, jest sztuką dawnych bogów, tytanów, a dziś paru ludzi, którzy zeskamotowali [zręcznie ukryli - W.S.] trik tragicznego światopoglądu ${ }^{42}$.

Jeśli jeszcze nie całkiem jest to jasne, to rozwiązujmy tę zagadkę dalej, razem z Marcelim Kiziorem-Buciewiczem, jednym z protagonistów Jedynego wyjścia. Chodzi o moment, w którym „biedne, ograniczone” Istnienie Poszczególne (w tym wypadku Marceli) „przeciwstawia się w samym fakcie swej egzystencji" Istnieniu w całości. Ja i świat cały. W takim to momencie, powtarza Witkacy, doświadcza się czegoś najcenniejszego w życiu, odczucia „takości”, nagłego doświadczenia siebie i świata w jednym ${ }^{43}$. Schopenhauer nazywał to odczuciem ,identyczności teraz we wszelkim czasie”, będące „istotnym wymogiem filozoficznego nastawienia”44. Mar-

40 Tenże, 622 upadki Bunga..., s. 123.

41 Tenże, Dramaty, t. I, s. 159.

42 Tenże, Jedyne wyjście, s. 79, 158, 161.

${ }^{43}$ Cały ten wywód: tamże, s. 101.

${ }^{44}$ Formuła przejęta przez Schopenhauera z filozofii indyjskiej: „tat twam asi”, czyli „to ty jesteś tym”. A. Schopenhauer, Zur Lehre von der Unzerstörbarkeit unseres wahren 
celi, malarz, jest dobrze wytrenowany w takich bezpośrednio, jak w błyskawicy, odczuwanych chwilach, z których rodzi się dzieło sztuki. By choć trochę przybliżyć nam, czytelnikom, istotę tego momentu, przywołuje obraz: to przedmiot $\mathrm{z}$ innego wymiaru ducha rzucony w gładką taflę codzienności. Sam moment wrzucenia jest istotny; potem, jako świadectwo, wspomnienie i refleksja, pojawiają się, jak kręgi na wodzie, myśli o tym, że jestem, choć mogłoby mnie wcale nie być, o Nicości, o pustym miejscu po obietnicy wieczności.

Mamy w ręku wszystkie elementy potrzebne do rozwiązania zagadki, jednym z nich jest jej forma, paradoks, sprzeczność, przechodzenie między „tak albo tak”. Rozwiązaniem jest jedność, a dokładnie: zgoda z niejasną dla człowieka jednością całego bytu, którą Witkacy ukrył w ciągłej oscylacji między istnieniem świata i cząstkowym istnieniem „moim”, między ,jestem” i „nie jestem”. Istnienie jest wplątane w Nicość, w tę granicę doświadczenia i negatyw Istnienia.

Witkacy lubił zagadki, sporo ich jest w jego sztuce ${ }^{45}$, a jeśli pojawia się ona w tekście filozoficznym, to nie dlatego, by unikać odpowiedzi albo pozostawić ją w mgle domysłów i niedopowiedzeń. Wiadomo, że nie zgadzał się z tezą Wittgensteina, że „o czym nie można mówić, o tym trzeba milczeć”. Nie ma takiego doświadczenia, przeżycia, którego nie da się opisać - a przynajmniej tego spróbować. Zagadka, paradoks jest retoryczną figurą dochodzenia prawdy. Przypomnijmy znowu Schopenhauera.

Thrasymachos. Więc czym jestem po śmierci? - Jasno i dokładnie!

Philalethes. Wszystkim i niczym.

THRASYMACHOs. No właśnie! Jako rozwiązanie problemu sprzeczność. [...]

Philalethes. Odpowiedzieć na transcendentne pytania w języku stworzonym dla poznania immanentnego może prowadzić do sprzeczności ${ }^{46}$.

U Schopenhauera można również znaleźć źródło Witkacowskiej zagadki, czyli ideę sprzeczności tkwiącej u samej podstawy istnienia: „W nieskończonej przestrzeni i nieskończonym czasie ludzkie indywiduum znajduje siebie jako skończone, więc jako przeciwieństwo tej nieuchwytnej wielkości, w którą zostało wrzucone..." ${ }^{47}$.

Zdanie-zagadka po raz pierwszy pojawia się w Marzeniach improduktywa, a wraz z zagadką treść i metoda filozofowania Witkacego. Ta wczesna praca okazuje się istotnym szkicem projektu, z którego w przy-

Wesens durch den Tod (Parerga und Paralipomena II), [w:] tenże, Zürcher Ausgabe, Werke in zehn Bänden, Band IX, Zürich 1977, s. 295 (dalej cytowane jako: Werke i rzymski numer tomu) (tłumaczenie - W.S.).

45 Pisze o nich J. Gondowicz (Paradoks o autorze, Kraków 2011, s. 132).

46 A. Schopenhauer, Werke, t. IX, s. 302 (tłumaczenie - W.S.).

${ }^{47}$ Tenże, Die Welt als Wille und Vorstellung, [w:] Sämtliche Werke, oprac. P. Deussen, t. 1, München 1911, § 57, s. 366. 
szłości powstanie system filozofii Witkacego: $\mathrm{z}$, ,ja” - monadą - Istnieniem Poszczególnym w centrum, przeżywającym bezpośrednio siebie, swoją samotność w świecie, zdolnym do uczucia metafizycznego i w introspekcji dotykającego Tajemnicy Istnienia, „otchłani bez dna”.

Lecz ani $\mathrm{w}$ tym projekcie, ani $\mathrm{w}$ powieści o Bungu nie znajdziemy prostego wyjaśnienia „kierowniczej idei”. Czy mogła nią być Schopenhauerowska „wola”? Młody Witkiewicz waha się między aprobata a krytyką, nie przyznając dokładnie, ile $\mathrm{z}$ systemu niemieckiego filozofa przejął ${ }^{48}$. Możliwe też, że „kierownicza idea” składała się z wielu myśli krążących wokół centralnego tematu, sytuacji ,ja”, Istnienia Poszczególnego w świecie, których to myśli syna Stanisław Witkiewicz mógł być od lat świadom, gdyby zwracał na nie większą uwagę. Czy pozytywna, tłumacząca sprzeczności, wszystko porządkująca idea byłaby w stanie ująć to, co grało w duszy młodego Witkiewicza? Problemu Istnienia nie można opisać pozytywnie, twierdził. Nicość jako odwrotność, negatyw, dramatyczny wymiar Istnienia, ma większe szanse na ujawnienie bytu; Nicość to przynajmniej istotna część składowa tej idei kierowniczej, o której mowa w liście ojca - nadaje myślom sceniczną głębię i pomaga w jeden spektakl

48 Młody Witkiewicz czytał Parerge $i$ Paralipomene Schopenhauera, i to nie tylko Szkice do historii filozofii. Jan Gondowicz zauważył, że Nienasycenie zaczyna się od historii opowiedzianej przez Schopenhauera o psie trzymanym na łańcuchu (Nachträge zur Lehre vom Leiden der Welt, § 153). W Marzeniach improduktywa i w $O$ dualizmie przejmuje Witkacy całe konstrukcje myślowe niemieckiego filozofa, podczas lektury Schopenhauera kształtuje się jego filozoficzne myślenie - nawet swoją podstawową pracę filozoficzną nazywał „Główniakiem” (Hauptwerk). „Wola” u Schopenhauera to zasada „trzymająca” świat, pierwotny napęd utrzymujący życie, które dzięki tej sile ciągle reprodukuje się w gatunkach, w zapładnianiu, w rodzeniu i umieraniu. W woli wyraża się transcendentny wymiar istnienia, jądro wszystkich indywidualnych istnień. Natomiast przejawami woli, jej przemijającymi zjawiskami są indywidualne, śmiertelne osobniki, z ich ograniczonym czasowo życiem, fizjologią, mózgiem i świadomością, ciągle się powtarzające i o swej wyjątkowości przekonane kopie, ciągle ci sami aktorzy. W nich, w każdym z osobna, zawiera się wymiar immanentny bytu. Z tej nauki Schopenhauera o dwu stronach istnienia mógł Witkacy wyczytać własną koncepcję dwoistości bytu, w której akcent położy jednak na dramatycznych próbach śmiertelników, by w ,ja” pogodzić ze sobą skończoność z nieskończonością bytu - albo, jeśli to niemożliwe, to przynajmniej to pęknięcie zrozumieć. Ten aspekt był dla Witkacego ważniejszy aniżeli próba opisania świata wedle jednego pomysłu („Schopenhauer [...] łudzący się, że przez słowa objaśnił tajemnicę bytu”, pisał Witkacy w Marzeniach improduktywa, s. 14). Pojęcie Jedności $w$ Wielości wiele zawdzięcza, przypuszczam, pojęciu woli rozumianej jako siła przenikająca i jednocząca wielość całego stworzenia; wola to „das Ding an sich” (rzecz sama w sobie, formuła często przywoływana przez Witkacego), i jej obiektywizacje w świecie. Stąd przychylność Witkacego dla panteizmu, jedynej możliwej religii, stąd też przejęta od Leibniza koncepcja żywej materii. Z koncepcji „woli” zostało w myśleniu Witkacego także zainteresowanie freudyzmem opisującym siłe erotyzmu (Freud, Adler i Jung cenili Schopenhauera) czy książką Kretschmera o typach charakteru (Körperbau und Charakter), a także zainteresowanie zjawiskami parapsychicznymi, które Schopenhauer uważał za działanie woli.

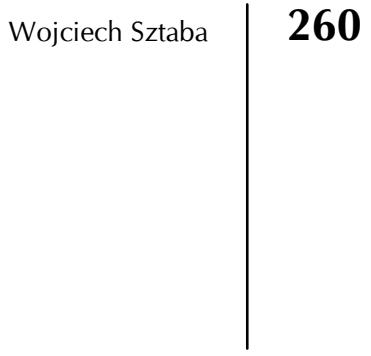


ująć „wszystkie rozbieżne władze i poruszenia duszy”. Ale czy Nicość może w ogóle „kierować”? Dokąd może prowadzić?

Siła Nicości, gdy o niej myśleć, jest wielka. „Das Nichts selbst nichtet”, pisał Heidegger w 1929 roku w Was ist Metaphysik. „Nic” ma wiele postaci, nie jest po prostu niczym, nie znaczy tylko rezygnacji, niemożności znalezienia prawdy. Witkacy mógł wyczytać u Nietzschego, że „Nic” posiada też pozytywny wymiar, należy do strategii aktywnego nihilizmu, oznacza możliwość przezwyciężenia rezygnacji i pesymizmu, jest początkiem, tabula rasa, ,sprowadzeniem na powrót wartości ze sfery bezwarunkowości i absolutu do zakotwiczonego w rzeczywistości uwarunkowania i względności”49. Poeta Gottfried Benn głosił, że nihilizm nie jest niszczący, przeciwnie - jest formotwórczy: Nicość jest potęgą domagającą się formy, a nawet może stać się źródłem szczęścia!50. Myśl, że na początku sztuki jest Nicość, należy do ideologii powieści 622 upadki Bunga: „Trzeba mieć chaos w sobie, żeby zrodzić gwiazdę” - cytuje Bungo Nietzschego. Trzeba z pustki stworzyć sztukę i siebie, „musisz się zdobyć na pustkę”, „tworzyć z Niczego...”, „wielka sztuka powstaje w zupełnej pustce, tam, gdzie życie już nie dochodzi”"51. Dwadzieścia lat później, w Jedynym wyjściu dodaje: „Nie darmo dawni mędrcy widzieli w Nicości pojęcie twórcze i dodatnie, jako odskocznię i kryterium. Dziś uważane jest ono za bezpłodną marę pojęciową i niesłusznie"52.

Tworzyć z nicości, wynaleźć wszystko od początku, sprowadzić „do naszego środka, do niewyczerpalnych głębi naszych uczuć, do „świadomości siebie, kiedy cisza bez dna zalegnie między dwoma uszami na chwilę, co wiecznością się staje" 53 - to niezwykła, wyjątkowa możliwość, otwierająca się przed młodym artystą i filozofem. Ale czy dla wszystkich i zawsze? Prowadzić może przecież także, wie to Bungo, „do tak zwanego babrania się we własnej pustce i artystycznego onanizmu”54.

\section{O rodzajach Nicości}

Od pojęcia „absolutnej Nicości” zaczyna Witkacy we Wstępie filozoficznym do Nowych form $w$ malarstwie swój pierwszy wykład o budowie świata. Nicość Absolutna, czyli niemożność „przyjęcia Istnienia w ogóle”,

49 B. Hillebrandt, Ästhetik des Nihilismus..., s. 101.

${ }^{50} \mathrm{G}$. Benn, Gesetz von der formfordernden Gewalt des Nichts, 1932, wg B. Hillebrandta, Nihilismus, s. 129,69 .

51 S.I. Witkiewicz, 622 upadki Bunga..., s. 438, 32, 183.

52 Tenże, Jedyne wyjście, s. 100.

${ }_{53}$ Tenże, Marzenia improduktywa, s. 15, 14.

54 Tenże, 622 upadki Bunga..., s. 166. 
„jest nie-do-przyjęcia”, jak sformułuje to w Twierdzeniu 1 swej już rozwiniętej filozofii ${ }^{55}$. Nicości Absolutnej nie można pomyśleć, bo nie możemy przecież przestać myśleć o przestrzeni, wyobrazić sobie, że jej nie ma, dowodzi więc nie wprost, lecz okrężną drogą, że Istnienie jest. Natomiast inna Nicość, o której opowiada Witkacy, „zwykła”, doświadczana w codziennym życiu, jest troską ludzi: to miejsce, które pozostaje po utraconym sensie życia, po Bogu i innych wyższych instancjach odpowiedzialnych za urządzenie kosmosu, kiedy przestaje się w nie wierzyć.

Ta dotkliwie doznawana Nicość pojawia się na końcu wykładu Witkacego, jako odczucie samotności człowieka (Istnienia Poszczególnego) stojącego w całej swej przypadkowości wobec „nagiego” faktu istnienia, nieusprawiedliwionego ani religią, filozofią czy sztuką, bez wytłumaczenia tego, dlaczego człowiek jest. Bez nadbudowy, bez „łagodnych zasłon” Tajemnicy, człowiek jest bezbronny wobec „Istnienia w jego metafizycznej okropności”, które nagle się zaczyna i nagle kończy, bez sensu. Nicość to metafizyczna okropność bytu, czyli niemożność znalezienia odpowiedzi na pytanie „skąd przychodzimy, gdzie jesteśmy i dokąd zmierzamy”, jak zatytułował swój obraz ulubiony malarz Witkacego.

To Nic, na które nie ma i nie będzie odpowiedzi, to niezgłębiona przepaść, nierozjaśnialna, Wieczna Tajemnica Istnienia. Nicość i Tajemnica stoją w systemie Witkacego blisko, dotykają się, może określają to samo. Kiedy pisze, że uznaje „za jedynie wartościowe te momenty w życiu, w których człowiek zagłębia się myślą w przepaść bezdennej Tajemnicy”, pisze zarazem o chwili pochylania się nad Nicością.

Przypuszczalnie z lektury Schopenhauera przejął Witkacy program nihilizmu - bardziej niż od Nietzschego, z którym w późniejszym czasie nie chciał z jakiegoś powodu być kojarzony. (Może z powodu ojca, który używał cytatów z Nietzschego jako maksym życiowych, a tym samym przyprawiał im, mówiąc po gombrowiczowsku, pupę.) W rozdziale dwunastym w Parerga und Paralipomena, Uzupetnienia do nauki o nicości bytu znaleźć można myśli Schopenhauera pasujące do programu Witkiewicza. „Ta nicość znajduje wyraz w całej formie bytu, w nieskończoności czasu i przestrzeni, i skończoności jednostki w obu; w nietrwałej teraźniejszości, która jest jedynym sposobem bytu w rzeczywistości; w zależności i względności wszelkich rzeczy; w ciągłym stawaniu się bez istnienia; w ciągłych życzeniach bez spełnienia; w ciągłym powstrzymywaniu śmierci, z czego składa się życie, aż do jego przezwyciężenia”. Rozczaro-

55 Tenże, Pojęcia i twierdzenia implikowane przez pojęcie Istnienia, [w:] Pisma filozoficzne $i$ estetyczne, t. 3: O idealizmie i realizmie, s. 414 passim. 
wanie do życia, niemożliwego jego spełnienia, nicość ziemskich przyjemności, brak celu, wieczne „nienasycenie indywidualnej woli”, a przede wszystkim nuda spowodowana tym, że „życie nie ma rzeczywistej, prawdziwej treści", to stały motyw w teorii i w sztuce Witkacego ${ }^{56}$.

Ale jest i różnica: dla Schopenhauera Nicość, brak sensu życia to końcowa, ostateczna diagnoza. Życie człowieka zdeterminowane jest przez ślepą wolę, a ucieczkę przed nią umożliwia Nirwana, zaprzeczenie woli, co osiągnać można także dzięki sztuce. Na końcu czwartej, ostatniej księgi jego dzieła Świat jako wola i przedstawienie stoi słowo „Nichts”. Według Witkacego sztuka pomaga wprawdzie wytrzymać okropność egzystencji, nie jest jednak zaprzeczeniem życia; musimy zaakceptować Nicość jako konieczny warunek Istnienia, jako niezbędne tło dla „okropnie jaskrawo świecącej z czarnej otchłani bytu - Wiecznej Tajemnicy"57. Nie pozostajemy z pustymi rękami: właśnie na czarnym ekranie Nicości pojawia się pojęcie dwoistego istnienia, czasu i przestrzeni, ograniczoności i jedyności, takości naszej egzystencji („czemu jest to, a nie tamto”58). Uświadomienie sobie Nicości jest straszne, bo uświadamia nam naszą samotność, mówi Witkacy, dzięki temu mamy jednak możliwość odczuć (a nie tylko zrozumieć) choć na moment Istnienie, to własne, poszczególne, będące częścią wielości Istnień. Jest to Nicość z kompensacją, z „nagrodą", ale nie w zaświatach, lecz w nas samych, w immanentnym przeżyciu. Witkacy nie chce przezwyciężać nihilizmu, jak mógłby zresztą, skoro spotkanie $\mathrm{z}$ nihilizmem przynosi wgląd $\mathrm{w}$ siebie, doświadczenie metafizyczne odczute w całym psychofizycznym ,ja”.

Z czasów intensywnej lektury Schopenhauera pochodzi krótki tekst O dualizmie (1902), a w nim wczesny filozoficzny „obraz” stanu rozmyślania o świecie, najmocniejsza chyba strona theatrum philosophiae Witkacego:

Każdy człowiek ma chwile, gdy wydaje się niczym wobec otaczającego go świata. Po co malować, grać, tworzyć i w ogóle żyć, kiedy my należymy do systemu, „Drogi Mlecznej”, którą światło przebiega co 65 lat, a gdzieś w niezmierzonych odległościach wiruje mgławica Andromedy i tysiące innych niezmierzonych światów. Razy 1000 razy, nieskończoność razy nieskończoność jest nieskończoność i dlatego gdziekolwiek staniemy, zawsze po obu stronach otwierają się przepaście bez dna, nad którymi zmuszeni jesteśmy piąć się skalistą granią życia bez wytchnienia i bez przerwy. Z drugiej strony, patrząc w samego siebie i w innych

56 A. Schopenhauer, Nachträge zur Lehre von der Nichtigkeit des Daseyns, [w:] Werke IX, s. 307, 309, 313. O recepcji Schopenhauera w Polsce: Jerzy Tuczyński, Schopenhauer a Młoda Polska.

${ }^{57}$ S.I. Witkiewicz, Narkotyki - Niemyte dusze, s. 63.

58 Tenże, Nowe formy $w$ malarstwie, [w:] Pisma filozoficzne i estetyczne, t. 1, opracował i przypisami opatrzył J. Leszczyński, Warszawa 1974, s. 128. 
widzi się jasno marność wszelkich umysłowych koncepcji. Czym jest sobie czas i przestrzeń i przyczynowość rządząca piekielnym chaosem światów i wymoczki w kropli wody i mgławice w nieskończonych obszarach niebieskich wobec samego życia duszy ludzkiej. Czym to wszystko wobec zadumania pełnego przeczuć nad własną istotą, czym to wobec straszliwej siły i świadomości siebie, kiedy cisza bez dna zalegnie między dwoma uszami na chwilę, co wiecznością się staje. I tak walczą w człowieku te dwa kierunki, a wynikiem ich walki jest to życie tak nędzne, brudne i marne, a jednak tak niepojęte, pełne blasków wspaniałe i nieskończone ${ }^{59}$.

Ten obraz dobrze jest mieć przy sobie w czasie czytania innych jego tekstów, także tych późnych.

\section{Peyotlowe wizje Nicości}

Witkacy opisuje w Narkotykach ciąg wizji wywołanych peyotlem, pełen zachwytu nad ich przechodzącym wszelkie wyobrażenie bogactwem form, barw i historii. Wielcy artyści dawnych czasów musieli znać peyotl - pisze.

Pewien fragment tego opisu zwraca szczególną uwagę - tak przez treść, jak przez formę. Zbudowany jest z dwóch dłuższych zdań symetrycznie ułożonych po obu stronach trzeciego, krótkiego, w ten sposób podkreślających jego samodzielność pośród innych zdań na stronie. Witkacy obserwator próbuje zajrzeć poza przesuwające się na ekranie świadomości obrazy:

I dobra jest przy tym ta aż dźwięcząca sobą cisza wizji stwarzanych przez azteckiego Boga Światła - cisza spotęgowana niewiarygodnym korowodem zdarzeń, który w jej objęciach przepływa przed nami w nicość. A jednak nicość ta nie jest zupełna. Coś zostaje po peyotlowym transie niezniszczalnego, coś wyższego stwarza w nas ten prąd widzeń, z których wszystkie prawie mają głębie ukrytego w nich symbolizmu rzeczy najwyższych, ostatecznych ${ }^{60}$.

W tych zdaniach wyraża się przeczucie jakiejś innej drogi, którą dostają się do nas „inne” obrazy, może z obszarów graniczących z Tajemnicą Istnienia - nie te powstające w wyobraźni, ani te postrzegane wzrokiem. O takich obrazach „przychodzących z całkiem innej strony, czyli od wewnątrz", wspominał Schopenhauer w rozprawie o snach i zjawach ${ }^{61}$.

59 Tenże, Marzenia improduktywa, s. 14.

60 Tenże, Narkotyki - Niemyte dusze, s. 132.

${ }^{61}$ A. Schopenhauer, Versuch über Geistersehen und was damit zusammenhängt, [w:] Werke, t. VII, s. 250 passim. 
Więc Nicość można obejrzeć, nie jest pusta, jest „miejscem”, z którego rodzą się i do którego powracają rzeczy. Witkacy filozof nie jest kimś innym niż Witkacy malarz, pisarz i dramaturg - obrazy oraz metafory towarzyszą i wyrażają jego myśli. „Przetłumaczona” na obraz Nicość jest niebytem szczególnym - takim jak czerń na kinowym ekranie, z której wyłania się i w której zanika obraz. Albo jest teatralną sceną, najpierw ciemną, potem rozświetloną reflektorem. Albo częścią odwiecznego teatru natury z jego koleją rzeczy, od mroku do światła, od zmierzchu do ciemności. Jak pisał francuski matematyk Louis Bertranda Castel (16881757): „Wszystko przychodzi z czerni, by zagubić się w bieli”62.

\section{Książka o Nicości}

O czym jest pierwsza powieść Witkacego 622 upadki Bunga? O stawaniu się artystą, o poszukiwaniu siebie i kształtu swojej sztuki? O niespełnieniu i porażce projektu życia i sztuki? O grupie demonizujących się wzajemnie młodych dekadentów zakopiańskich? O niszczącym seksie? O wszystkim po części, lecz głównie pierwszym tekstem literackim Witkacego o nicości i o artyście w czasie marnym ${ }^{63}$. Formę powieści opracował starannie w szczegółach i w całości kompozycji, wypróbowując różne środki stylistyczne. Nie ulega wątpliwości, że stworzenie literackiego dzieła sztuki było jego zamiarem, takiej sztuki, która, jak głosił Nietzsche, ma ratować przed Nicością. „Nie ma pesymistycznej sztuki... Sztuka potwierdza. Hiob potwierdza... Nihilizm nie zostanie przezwyciężony przez sztukę, która zaprzecza życiu, przeciwnie... sztuka potwierdza życie... sztuka $\mathrm{w}$ istocie jest potwierdzeniem, błogosławieństwem, ubóstwieniem życia"64.

Sztuka zajmuje w powieści wiele miejsca - muzyka i przede wszystkim dwie uprawiane przez samego autora dziedziny - malarstwo i literatura. Ta ostania przedstawiona pod postacią obszernych prób literackich Bunga i jego przyjaciół, jako teksty w tekście: powieści, wierszy, utworu dramatycznego, a także pamiętników, których forma zwraca uwagę przez brak wszelkiej stylizacji: „pisane już zupełnie bez literatury”65. Nade

62 Według R. Holzemmer, Th. Honickel, Tout vient du noir et se perd dans le blanc, ZDF/Arte 2012

63 Jako gatunek literacki (Künstlerroman) pojawił się ten rodzaj powieści pod koniec XIX wieku w Niemczech, nieprzypadkowo równolegle do pierwszych manifestów literatury nihilistycznej stawiającej m.in. także problem artysty na głównym planie, np. w powieściach Tiecka, Wilhelm Lovell i Franz Sternbalds Wanderungen. Eine altdeutsche Geschichte (1798).

${ }^{64}$ F. Nietzsche, Sämtliche Werke, t. 13, s. 241.

65 S.I. Witkiewicz, 622 upadki Bunga..., s. 445. 
wszystko literatura jest obecna jako 622 upadki Bunga, jako pojemnik na inne teksty literackie, na obrazy i muzyczne kompozycje, a zarazem jako próba sztuki, konkurująca z dziełami powieściowych artystów.

Wiadomo, że Witkacy odmawiał powieści miana sztuki, była dla niego miejscem na opowiadanie historii i wyrażanie poglądów, także filozoficznych, i tylko od czasu do czasu mogła stwarzać sposobność dla artystycznych przeżyć66. Ale ta koncepcja powieści-worka pojawiła się u niego dopiero później, zaś w czasie pisania Bunga opcja literatury jako sztuki, nawet „czystej”, jeszcze istniała. Baron Brummel, przyjaciel Bunga, rozważając pisanie własnej powieści:

pod wpływem lektury Flauberta [...] doznał jakiegoś wewnętrznego olśnienia. [...] Intuicyjnie zrozumiał, że forma literacka, będąca kombinacją form pojęciowych, które w pewnych układach mogą wyrażać bezpośrednio najbardziej niedające się ująć treści psychiczne, symbolizujące metafizyczne prawo istnienia, jest jedyną formą, w której on [...] przejawić się może, tworząc jednocześnie dzieła czystej sztuki ${ }^{67}$.

Dokładnie tak samo będzie Witkacy opisywać w swych późniejszych pracach teoretycznych działanie formy w malarstwie, w teatrze i w poezji: jako kombinację form w pewnym układzie! Kuszenie św. Antoniego Flauberta, książka, która olśniła Brummela, olśniła też i Witkacego. Jego wielokrotne powroty w malarstwie do tematu Kuszenia świadczą o fascynacji powieścią, jej literacką, intensywną, psychodeliczną niemal formą.

$*$

Powieść podzielił Witkacy na trzy rozdziały, te z kolei na trzy podrozdziały, przy czym funkcję ostatniego spełnia dopisane Zakończenie. O kompozycji powieści pisze w Przedmowie: „Jedynym tłem jest lekko naszkicowany pejzaż, a dążyłem tylko do tego, aby ukazać potworność ludzkich przeżyć na tle piękności natury". I jeszcze jedna istotna uwaga autora, jakby uprzedzająca zarzuty krytyki: „Pewna monotonia [...] jest programowa". Stosować ją będzie w różnych sytuacjach, w różnym znaczeniu - jako znak nudy i pustki, znak wiecznych powrotów, czy wreszcie jako efekt formalny.

„Potworność ludzkich przeżyć" rozpisał na role czy raczej figury tworzące alegorię upadku, która opowiada o dramatycznym poszukiwaniu sensu życia, sztuki i formy artystycznej (ich symboliczną figurą mogą być „potwory”, jak nazywa Bungo swoje kompozycje rysunkowe), o udrękach

66 Zob. W. Sztaba, Obrazy z życia monady, [w:] Witkacy i inni. Z kolekcji Stefana Okotowicza i Ewy Franczak, Warszawa 2011, s. 52-58.

67 S.I. Witkiewicz, 622 upadki Bunga..., s. 401 passim. 
(i rozkoszach) erotycznych przeżyć, o potwornych animalistycznych popędach i pożądaniach, wreszcie o stale obecnym widmie nicości, tym największym potworze, który grozi, straszy i kieruje myślami, uczuciami i czynami protagonistów jak marionetkami.

Kompozycja powieści przypomina utwór muzyczny. Występują w niej tematy główne, poboczne oraz ich wariacje, spotykają się, przeplatają, wracają, a liczne powtórzenia wywołują zamierzoną przez autora monotonię. Tematom nadał Witkacy napięcie podobne temu, które gra tak wielką rolę w jego teorii sztuki i które w malarstwie nazywał kierunkowym, a w teatrze - dynamicznym: każda forma ma na obrazie swój odczuwalny kierunek i rytm, każda jakość posiada swoje napięcie, ma je słowo, zdanie, treść, gest, a rozłożone w czasie spotykają się, tworząc węzły sił68. Szczególnie trzy tematy i ich napięcia „trzymają” kompozycję całej powieści: obrazy natury, erotyzm oraz myśli związane $\mathrm{z}$ sensem i Tajemnicą Istnienia. Wszystkie motywy, jak zobaczymy, splotą się w finale w jeden, nie do rozplątania węzeł.

$$
*
$$

Tytuł pierwszej powieści Witkacego brzmi jak żart, Bungo przypomina imię clowna albo psa; liczba upadków może po prostu znaczyć: „dużo”, „bardzo wiele”, „niemal bez końca”. Imię Bungo nie jest jednak wymysłem Witkacego, odnosi się albo do rodzaju japońskiego pisma (a więc do ideogramu, do szyfru), albo do tytułowego bohatera jezuickiego dramatu o japońskim księciu, chrześcijańskim męczenniku. Bungo to brzmi śmiesznie - ale Bungo to ten, co ginie za wiarę ${ }^{69}$. Wedle rachunku „apokaliptycznego" liczba 622 ma wielkie znaczenie ${ }^{70}$. Jej podstawą jest imię apokaliptycznej bestii z Apokalipsy św. Jana: „Tu jest [potrzebna] mądrość. Kto ma rozum, niech liczbę Bestii przeliczy: liczba to bowiem człowieka. A liczba jego: sześćset sześćdziesiąt sześć”. Jeśli odjąć liczbę 44, która pojawia się w III części Dziadów Mickiewicza („A imię jego czterdzieści i cztery"), to otrzymamy liczbę upadków Bunga. Nawet jeśli wskrzesiciel narodu, zbawca wyrosły na polskiej ziemi, uszczknie 44 jednostki z 666 , to i tak bestii zagłady wystarczy siły na to, by świat cały zniszczyć.

Nie bez znaczenie dla wyboru tytułu jest również to, co Witkacy wyczytał w wydanej w 1910 roku, więc w czasie pisania Bunga, powieści Tadeusza Micińskiego Nietota. Księga tajemna Tatr (Witkacy występuje

68 Tenże, Teatr, [w:] Pisma filozoficzne i estetyczne, t. 1, s. 342 passim.

69 W. Sztaba, Skad się wziąt Bungo?, „Pamiętnik Literacki” 2002, XCIII, z. 4.

70 K. Damar, Rachunek apokaliptyczny, <www.kunstbriefe.de/Witkacy_rachunek.html>, styczeń 2012 . 
w niej jako książę Hubert, a Miciński to z kolei Mag Childeryk w Bungu). Są w niej potwory, Czarne Msze, „katedry pełne ukrzyżowanego Lucifera”, „Bestia triumphalis reakcyjnych zbirów i potwarców” i - szczególnie - „Antychrysty o 666 źrenicach”!71. Apokaliptyczna wizja obecna jest również w dramacie Micińskiego W mrokach Złotego Pałacu czyli Bazylissa Teofanu, którego pierwszą wersję z 1905 roku znał już Witkacy. "O głębiny ducha ludzkiego" - pisał Miciński we wstępie do dramatu „o tajemnice Jaźni, przejawiającej się w tych świetnych Apokaliptycznych czasach Bizancjum na szczytach jego potęgi, walczę przede wszystkim, teraz jak i zawsze"72. To, że podziwiany przez Witkacego Miciński był mesjanistą, może mieć znaczenie dla liczby $44 \mathrm{z}$ „rachunku apokaliptycznego”. „Jeszcze nie wygasła magiczna wartość słów, w które wierzyli dawniej nasi wieszczowie", przypomina Prokurator w Szewcach ${ }^{73}$.

W swoim eseju o apokaliptyce Witkacowskiej wizji Jan Błoński pisał: „Nie będziemy przecież wracać do Hezjoda czy do św. Jana"74. Wydaje się, że warto spróbować. Historia upadków Bunga, zaczynając się takim tytułem, nabiera wymiaru apokaliptycznego. Nawet jeśli tylko w małym, prywatnym wymiarze, w zwierciadle groteski, jest ona odbiciem grożącej wielkiej apokalipsy, która rzuca cień na wszystko, co się w powieści zdarza.

Czymże jest ten największy, oczekujący nas kataklizm? Zapewne Witkacy nie myślał o wojnach i katastrofach żywiołowych. Największą apokalipsą przykrojoną do naszych czasów, katastrofą, jaka może spotkać człowieka, i o której ciągle czytamy u Witkacego, to zostać wchłoniętym przez nicość i bezsens, przestać być świadomym siebie człowiekiem, zostać automatem. To groza, z którą żyją bohaterowie powieści: „Coraz bardziej czuł absolutne odwartościowanie wszystkiego i straszną pustkę w sobie i przed sobą"75. „Coraz mniej uświadamiał sobie, że jest naprawdę, a przyszłość zaczęła mu się wydawać jakąś czarną bezdenną nicością”.

Nicość to niekończący się temat rozmów w powieści: „Długo w noc mówili jeszcze ci panowie o niczym przez wielkie i niczym przez małe $\mathrm{N}$, ale nie doszli do zupełnego porozumienia". Oto myśli barona Brummela, w których słychać echo słynnego zdania Nietzschego o nihilizmie, o tym obcym przed drzwiami, „najbardziej niepożądanym ze wszystkich gości”:

71 T. Miciński, Nietota. Księga tajemna Tatr, Warszawa 1910, s. 11, 434, 466.

72 Tenże, W mrokach Złotego Pałacu czyli Bazylissa Teofanu, wybór i opracowanie T. Wróblewska, Kraków 1978, s. 9.

${ }^{73}$ S.I. Witkiewicz, Dramaty, t. III, s. 319.

74 J. Błoński, Trzy apokalipsy w jednej, „Twórczość” 1976, nr 10.

75 S.I. Witkiewicz, 622 upadki Bunga..., s. 355, 358, 367, 400 (kolejne cytaty w tym rozdziale, s. 22-23).

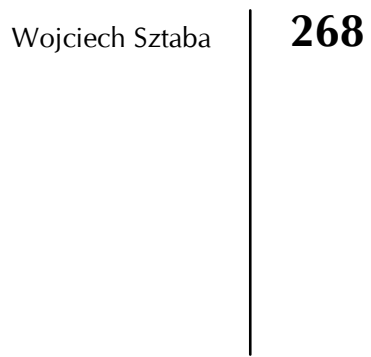


Jakby z jakiejś niezmierzonej odległości chwil, które dawno umarły, jakby z wieczności bez trwania oczy moje patrzą w siebie, ale od środka. Nieznacznie, bez najmniejszego szelestu, ktoś obcy, jakiś przerażający człowiek we mnie żyjący, przesunął punkt rzucający mojego intelektu o kąt nieskończenie mały. I wszystkie najtrwalsze wartości, żelazne prawa, kamienne milczenia niepoznawalnych głębi stają się mdłą galaretą w potwornych łapach tego odśrodkowego spojrzenia. Jest to siła, której nie ma; siła, która stwarza siebie samą w chwili działania, siła, która jest funkcją nicości wkraczającej w rzeczywistość. [...] Nicość zapłodniona przez samą siebie wydała te wszystkie ślepe, przełamane $\mathrm{w}$ istocie swej potwory, które patrzą z samych głębi mojej istoty.

Brummel wpuścił już przybysza do siebie, gość stał się jego lokatorem. Witkacy jest mistrzem introspekcji, bierze pod lupę myśli i uczucia, zauważa wszystkie niewielkie „przesunięcia” w świadomości, potęgę siły, której nie widać, a która nagle zmienia widzenie świata.

\section{O naturze i dziwności istnienia}

Obrazy przyrody są stale obecne w tle opowieści o losach targanych emocjami ludzi. Wcięte $\mathrm{w}$ narrację, trwają od paru do kilkunastu zdań, czasem towarzyszą wydarzeniom przez kilka stron. Jak chór w greckim teatrze komentuja dramatyczne wydarzenia na scenie. Ten komentarz poprzez obrazy natury jest czasem konwencjonalnie symboliczny: noc, mrok, zapadający zmierzch, promienie słońca złocące postacie bohaterów albo groźne chmury, zawieja śnieżna czy wiosenna odwilż podkreślają, „podmalowują”, jak w filmie, nastrój i znaczenie scen: „Coraz bardziej czuł absolutne odwartościowanie wszystkiego i straszną pustkę $\mathrm{w}$ sobie i przed sobą. Góry robiły na nim jakieś niesamowite, groźne jak nigdy dotąd wrażenie"76. Idąc w odwiedziny do przyjaciela zamkniętego w domu wariatów, Bungo widzi niebo zrobione ,jakby z cieniutkiej tafli przezroczystego, seledynowego kamienia".

$\mathrm{Na}$ płowo-niebieskim niebie przesuwały się porozrywane lekkie obłoki, pędzone ciepłym zachodnim wiatrem. W cieniach na stoku góry, popod lasem, widać było błękitniejące płaty topniejącego śniegu. [...] Bungo przerwał i zapatrzył się z trochę głupkowatym zadowoleniem na strzępiasty obłok zbliżający się gwałtownie do słońca. Nagle cień padł na ziemię i zrobiło się chłodno.

Lecz jest w tych obrazach coś więcej niż symbolizm. Demonstrują obecność przyrody i zarazem jej dystans, obojętność wobec całej nadbu-

76 Tamże, s. 355, 389, 478, 480, 477, 68, 63, 165 (kolejne cytaty w tym rozdziale, s. 23-25). 
dowy ludzkich spekulacji77. Widoki gór o różnych porach roku, obrazy nieba i przesuwających się po nim chmur powtarzają się jak refren, jak pętla bez końca, z małymi, nieistotnymi zmianami. Otwiera się okno na inny, nieludzki świat, niezrozumiały, świat sam w sobie, cały czas istniejący równolegle do śmiesznej ludzkiej komedii. Te literackie pejzaże nie mają na celu ukazania wrażliwości malarskiej pisarza, jego umiejętności komponowania ze słów, barw i form realistycznego krajobrazu ,jakim go widzę"78, co postulował Stanisław Witkiewicz. Witkacy nie przywłaszcza sobie natury, nie opanowuje jej słowem, natura jest dla niego czymś obiektywnym. Myśli inaczej niż ojciec, który w związku z opisami przyrody u Mickiewicza pisał: „cała ta mowa, którą świat zewnętrzny przemawia przez zmysły do naszego umysłu, była dla niego zupełnie zrozumiała i jasna"79. Wręcz przeciwnie. W Witkacowskich opisach jest coś, co oddziela widza od natury, coś obcego, niezrozumiałego, jak noc, co „robiła wrażenie słonecznego dnia oglądanego w czarnym lustrze”. Każdy opisany pejzaż w powieści to ukryty cytat z Pascala o wiecznej i przerażającej ciszy nieskończonych przestrzeni. Czy z Boskiej komedii Dantego o nocy kontemplującej gwiazdy. Zawsze ma się wrażenie ciszy, nawet jeśli są to obrazy burzy, huraganu, śnieżnej zawiei, ale widziane $\mathrm{w}$ filmie bez dźwięku. „Wielkie, podarte wichrem obłoki przelatywały, zdawało się, tuż nad gnącymi się, gigantycznymi sosnami, a w czarnych plamach nieba migotały z przerażającą wyrazistością gwiazdy”. „Ta cisza jest głucha [...] Ta cisza jest matowa [...] Cisza jest cichszą od samej siebie..." to fragmenty słownej licytacji między Brummelem a Tymbeuszem.

Podobnie dramatyczna cisza panuje w „niemych” $\mathrm{z}$ istoty fotografiach i studiach olejnych fal morskich, powstałych w czasie pobytu Witkacego w Lowranie (1904) i w Bretanii (1911). Dramatyczne napięcie kierunkowe w tych przedstawieniach wzburzonej, groźnej natury było przede wszystkim formalnym celem artysty. Lecz czy do napięcia nie należy również znaczenie obserwowanego z brzegu żywiołu, tego obrazu opisanego już przez Lukrecjusza i od Kanta nazywanego wzniosłością? Jak ciągnące wysoko po niebie chmury wyrażają monotonię rytmu natury i przemijalność ziemskiego życia, tak powracające fale mówią o ciągłym powrocie i odchodzeniu, o pojawianiu się z nicości i o znikaniu w niejer.

77 Również Jan Gondowicz potwierdza ten moment emocjonalnego dystansu do pejzażu, „nadmiernej rozległości tej sceny, której nie zdoła wypełnić i usensownić żadne konkretne Istnienie Poszczególne”. J. Gondowicz, Paradoks o autorze, s. 191, 204.

78 Por. S. Witkiewicz, Tatry w śniegu, [w:] Wybór pism estetycznych, wprowadzenie, wybór i opracowanie J. Tarnowski, Kraków 2009, s. 220-222.

79 S. Witkiewicz, Sztuka i krytyka u nas, wyd. II, Warszawa 1891, s. 101.

80 Zob. J. Tuczyński, Schopenhauer a Młoda Polska, na temat motywu fali w poezji młodopolskiej m.in. s. 163, 175.

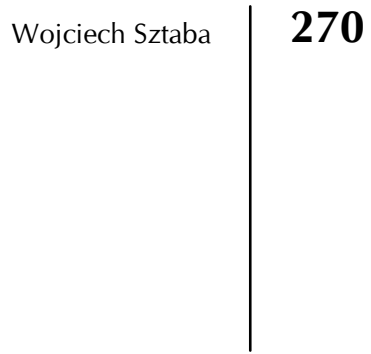


Obrazy natury wytwarzają napięcie oddalenia, odczuwane przez ,ja” wobec czegoś, co jest poza nim - w świecie. Jest to nic innego, jak przez Witkacego opisywane uczucie dziwności istnienia, uczucie metafizyczne. Lecz trzeba je zauważyć. Obrazy natury sa $\mathrm{w}$ powieści stale obecne, a wraz z nimi możliwość znalezienia tego, czego Bungo i jego przyjaciele tak rozpaczliwie szukają, a co cały czas okazuje się być tuż pod ręką. „Noc była cicha, wiosenna, noc pełna niepokoju, dziwnych, nieokreślonych tęsknot, tego «mal je ne sais quoi» [...] Bungo nazywał te stany «dziwnymi chwilami», w których na długi dystans widział jasno linię swego życia. [...] Im więcej żył, tym mniej miewał chwil takich...”. W alegorycznym wymiarze powieści przyroda odgrywa rolę straconej szansy. Liczne nocne nieba nad Bungiem przywołują w pamięci maksymę Kanta: „Niebo gwiaździste nade mną, prawo moralne we mnie". W kontekście licznych „upadków” bohatera brzmi to zdanie mocno ironicznie.

\section{O miejscach, czyli minidramatach}

Miejsca, w których przebywają ludzie, wnętrza, ulice, drogi, wyrażają w powieści, podobnie jak opisy przyrody, istnienie czegoś ponad, czegoś obcego, pozaludzkiego, dziwność, tajemniczość, może są śladem nicości, nawet w rzeczach zwykłych, ale inaczej przez pisarza zobaczonych. Witkacy buduje te sceny jak sekwencje filmowe, rozjaśnia je, zaczynając od ciemności i kończy wyciemnieniem; nie dzieje się w nich wiele, a mimo to w obrazach „chwila zdawała się posiadać napięcie” 81 .

Oto obraz wnętrza pokoju w świetle świecy, podwojony w ostatnim zdaniu:

Świeca drgała, jakby poruszana szybkim oddechem jakichś ust niewidzialnych. Ubrania w kącie wiszące na gwoździach, groźne, milczące, dziwnie nieruchome, zdawały się czekać tylko sposobności, by okrywając wcielenia chwil różnych, obcych już teraz, jakby należących do innych ludzi dawno już umarłych, rozpocząć ruchy bezrozumnie straszne. Olbrzymia szafa, pełna tajemnicy jakiejś straszliwej, zdawała się rozpękać od potwornego, cichego wysiłku. Zdawało się, że za chwilę roztworzy się sama i coś ukaże, co się dawno kryło w jej ciemnym wnętrzu. Krzesła tak dziwnie stały zgrupowane, że mimo woli kazały przypuszczać siedzące na nich postacie niewidzialnych gości, zajętych pełną grozy konwersacją. Kurzem pokryte niewielkie zwierciadło odbijało właśnie tę część pokoju ${ }^{82}$.

81 S.I. Witkiewicz, Pożegnanie jesieni, s. 42.

82 Tenże, 622 upadki Bunga..., s. 129, 204, 466, 487 (kolejne cytaty w tym rozdziale, s. 25-26). 
Oto opis koncertu pianisty Anodiona, ważny przez pierwsze intymne zbliżenie Bunga i Akne. W czasie koncertu postanowiono zgasić światło:

...zaległy nieprzeniknione ciemności, po czym zaczęła się na nowo muzyczna orgia... W przerwach któryś z panów zapalał papierosa i blask zapałki oświetlał całe zgromadzenie... Anodion zapalił papierosa i na chwilę Bungo ujrzał rozchylone usta Akne i przymknięte z wyrazem zupełnego oddania się oczy. Po czym znów nastała ciemność... Przez nie domknięte drzwi wpadła cienka smuga światła i po chwili z drugiego pokoju Bungo usłyszał najwyraźniej stłumiony płacz. Czarna dama wybiegła do drugiego pokoju, a smutny młodzieniec zapalił zapałkę, a potem lampę.

Oto Bungo w samobójczym nastroju idzie wieczorem po nasypie kolejowym; pociąg wyłania się z ciemności, mija go, tylne światła znikają w mroku.

Oddalał się szybko od miasta, idąc wzdłuż toru. Padał drobny śnieg i wiatr dźwięczał ponuro w telegraficznych słupach. Na lewo rozciągała się szeroka w tumanach lecącego śniegu pomarańczowo-czerwona łuna miejska, na prawo, z nieprzeniknionych ciemności, dął zimny, przejmujący wiatr. Bungo szedł coraz szybciej. Miał okropne uczucie, jakby w nim samym otwierała się jakaś potworna przepaść wypełniona bezwzględną nicością. [...] Z daleka dało się słyszeć sapanie dwóch lokomotyw i po chwili czerwone światła zabłysły na horyzoncie. Bungo zszedł parę kroków w dół nasypu. Wolno, z głuchym łomotem przewalał się ogromny towarowy pociąg. Otwarto piec w lokomotywie i jaskrawy pomarańczowy blask oświetlił kłęby dymu i chmurę śniegową. Po czym znowu nastała ciemność. Wagony pochylone na zakręcie przesuwały się jak widma... Błysnęła znowu latarnia na końcu pociągu i wszystko zniknęło w ciemnościach.

W 622 upadkach Bunga natura pojawia się już na pierwszej stronie z widokiem przez okno na jesienny, słoneczny krajobraz. Ostatni zaś krajobraz w powieści pochodzi z maja. Wieczór jest dramatyczny, huczy silny wiatr. „Nad ciemną massą gór, u stóp których widać było parę niepewnie mrugających światełek, kłębiły się olbrzymie czarne obłoki. Strzępy ich roznosił wicher po wyiskrzonym od gwiazd niebie”. Nadzieja na wiosenną odnowę, na wyzwolenie się Bunga z mocy demonicznej kobiety okaże się złudna. Drugie zakończenie, dopisane w 1919 roku, nie wspomina o porze roku, dzieje się już jakby poza czasem i definitywnie przypieczętowuje upadek Bunga. Ale natura jest i przy tym upadku obecna, jest wykonawczynią przeznaczenia: idąc przez las, Bungo wybija sobie oko na uschłej gałęzi świerka... 


\section{Orgazm najwyższej Rozkoszy}

Erotyzm, seks to następne, najbardziej życiowo naładowane dramatyczne napięcie spinające kompozycję powieści. Erotyczne sceny i obrazy nastawione na mocne wrażenie mają podniecać. Jakby już z perspektywy freudowskiej analizy widzi Witkacy w powieściowej parze kochanków ofiary erotycznego żywiołu, „w którym indywidua są bezwolnymi ofiarami jakiejś przerastającej je, dla nie znanych nam dalszych celów wytworzonej potęgi życia"83, doprowadzającej Bunga do utraty przytomności. Tak też mają działać opisywane w powieści obrazy kuszenia. Oto scena przypominająca obraz Klimta (Goldfische, 1902): „Nie tak, wstań - szepnęła Akne i odwróciwszy się tyłem do niego, uniosła szlafrok do góry. Bungo ujrzał przed sobą, zupełnie tak jak we śnie, dwie piekielnej białości półkule i stracił zupełnie przytomność w nie do wytrzymania rozwydrzonej rozkoszy wbijania się całą siłą w to rozżarzone do białości ciało. [...] Tego wieczoru Bungo raz po raz tracił przytomność"s4.

Witkacy nie tylko podsuwa Bungowi i czytelnikowi podniecające erotyczne obrazy, jakby prosto z pornograficznych zeszytów. Przyjmuje też strategię przeciwną, sabotuje dopiero co wytworzone napięcie erotyczne, pożądanie partnerów nagle się kończy, zainteresowanie seksem słabnie przez powtórzenia ciągle tych samych rytuałów, kopulacji za kopulacją. Wszelki sentymentalizm, wszelka „ładność”, estetyzacja miłości nie mają tu miejsca. Spełnienie jest fizyczne, trwa tylko chwilę, jak w scenie przypominającej z początku romantyczne dziewiętnastowieczne obrazy: „Pani Akne leżała z przymkniętymi oczami, z zupełnie przegiętą, zwisającą z brzegu łóżka głową, zastygła w potwornym kurczu rozkoszy, a rozsypane jak len włosy jej spadały aż na podłogę. Bungo patrzył na nią z zupełnym zachwytem”. Ale nagle zmienia się nastrój Bunga „...ogarnęła go zimna, okrutna złość. Chwycił Akne za rękę i szarpnął ją gwałtownie”. Obraz pięknej Akne znika, następuje zniechęcenie i nienasycenie ${ }^{85}$.

Również w malarstwie Witkacego nie ma miejsca na klasyczny „piękny” akt przedstawiający studium ciała, a jeżeli się raz pojawił, to tak, jak w powyższej scenie z Akne upozowaną na łóżku - jako akt „przerwany", wykpiony, zaprzeczony. Jedyny znany akt akademicki (trochę

${ }^{83}$ Cytat pochodzi wprawdzie z Niemytych dusz (rozdział o erotyzmie i psychoanalizie czyta się jak późny komentarz do Bunga), ale już w czasie pisania Bunga Witkacy przechodził terapię psychoanalityczną u doktora de Beauraina, no i znał Schopenhauera, którego kategoria „woli” jest właśnie tą „potęgą życia”. S.I. Witkiewicz, Narkotyki - Niemyte dusze, s. 217.

84 S.I. Witkiewicz, 622 upadki Bunga..., s. 371.

85 Tamże, s. 458 passim. 
w stylu Gauguina) nosi przewrotny i zarazem makabryczny tytuł: „Akt p. Brządzielskiej, która umarła na zapalenie kiszki ślepej"86.

Monotonia w opisach, zapowiedziana we wstępie do powieści, jest zamierzona. Dlaczego? Bo przez nią wkrada się w erotyzm nuda i rozczarowanie, których nie zrównoważą krótkie chwile rozkoszy ani nie przepędzą coraz wymyślniejsze i brutalniejsze praktyki erotyczne.

Mimo całej zmysłowości napięcie $\mathrm{w}$ powieści jest męczące i maniakalne - to negatywne napięcie erotyzmu nienasyconego, niespełnionego, na granicy nienawiści. Seks już od pierwszej romantycznej powieści nihilistycznej William Lovell Ludwika Tiecka jest przedstawiony jako ucieczka przed pustką. Także opisy seksualnych doznań w Bungu nie są nowymi obrazami ars amandi, lecz studium porażki ludzi, dla których nicość to tylko czarna przestrzeń, na której nie pojawia się nic.

$\mathrm{Na}$ przedstawienie tej sytuacji wynalazł Witkacy w krótkim zdaniu obrazową metaforę: „Bungo kupił duży, czarny, puszysty dywan i tarzali się po nim w strasznych konwulsjach nienasyconej żądzy" 87 . Nie czerwony, niebieski czy żółty, ale właśnie czarny. Scena, zobaczona z góry, przedstawia dwa splątane ze sobą ciała na czarnym prostokącie, czyli na tle „otaczającej nicości”. Nicość w sztuce Witkacego ma dwa kierunki: albo pozwala dojrzeć na jej tle rzeczy, których inaczej zobaczyć się nie da, i które na jej tle jarza się i wznoszą ku nam jako Wieczna Tajemnica Istnienia, albo jest jak kosmiczna czarna dziura, wchłaniająca w siebie czas i przestrzeń. Tej właśnie Nicości zdają się doświadczać najczęściej bohaterowie sztuk i powieści Witkacego.

Kochankowie z 622 upadków Bunga, już dawno wygnani z raju, utracili dar odczuwania dziwności istnienia poprzez miłość. Może z erotyzmem jest podobnie jak z peyotlem, o którego zażywaniu napisał Witkacy w Narkotykach: „Mają rację Indianie twierdząc, że kto niegodny ośmieli się zażyć peyotlu, nie oczyściwszy się wprzód ze swych grzechów, strasznie może być ukarany"88. Kara sa upadki. Każda kolejna kopulacja to kolejny upadek, nie poprzez „grzeszność” seksu, lecz przez fałszywe zamiary, przez erotyzm skażony kłamstwem, grą, egoizmem, poprzez wszystkie małe i wielkie upadki charakteru ${ }^{89}$.

86 Stanisław Ignacy Witkiewicz 1885-1939. Katalog dzieł malarskich, oprac. I. Jakimowicz przy współpracy A. Żakiewicz, Warszawa 1990, nr 175.

87 S.I. Witkiewicz, 622 upadki Bunga..., s. 387.

88 Tenże, Narkotyki - Niemyte dusze, s. 125. W Dzienniku Malinowskiego znajduje się taki zapis z 17 VI 1914: „Chcę dojść do bezwzględnej czystości płciowej przez ten czas. Inaczej nie ma się prawa do małżeństwa i na szczęście w małżeństwie”. B. Malinowski, Dziennik..., s. 334 .

89 Małgorzata Szpakowska i za nią Lech Sokół nazywają to trafnie „złą wiarą”. M. Szpakowska, Światopoglad Stanisława Ignacego Witkiewicza, Wrocław 1976, s. 138; L. Sokół, Witkacy i Strindberg..., s. 328. 
Dwa zakończenia powieści są w rzeczywistości jednym. Pierwsze, pozornie „dobre”, jest ostatnim, finałowym pokazem cielesnego, fatalnego magnetyzmu - kopulują, i choć Bungo opuszcza Akne, następuje to tak nagle, aż nie do uwierzenia, że nie jest to tylko kolejny upadek z kolejną przerwą i z fałszywymi, jak zwykle, postanowieniami ${ }^{90}$. Dopisane po latach zakończenie stawia kropkę nad i. Uschła gałąź, na której wybija sobie oko, co w konsekwencji doprowadza go do samobójstwa, to niewątpliwie symbol falliczny. Bungo, którego erotyczne wyczyny śledziliśmy przez kilkaset stron, ginie przez penetrację twardym, suchym patykiem (Donia Zizi, była kochanka Bunga, twierdziła, że był w ich stosunku kobietą...): „Kij mu w oko!”. To nie jest tylko nieszczęśliwy, choć symboliczny w wymowie wypadek (malarz, człowiek oka, ginie przez utratę wzroku), ale bezwzględna kara, jaką Witkacy wymierzył tytułowemu „bohaterowi” w swoim moralitecie.

Nie bez powodu Witkacy podnosi temperaturę erotycznych scen. Erotyzm wydaje się siłą nie tylko niszczącą, w seksie „zwraca się jeden stwór indywidualny $\mathrm{ku}$ drugiemu, szukając $\mathrm{w}$ transcendencji pozaosobowej uczuć ratunku przed absolutną samotnością zamkniętych beznadziejnie w swych nieprzepuszczalnych osobowościach żywych istot"91. A nawet „możliwym jest poznanie obcej psychiki, stopienie się $\mathrm{z}$ nią $\mathrm{w}$ jedność w żarach jakiejś straszliwej miłości, w której naprawdę ciało z duchem stanowi absolutną jedność, choćby za cenę unicestwienia”.

Seks jest też obietnicą wzmożenia potencji twórczej, i Bungo myśli też o tym, by w ramionach Akne „rozwiązać siebie jako artystę”. We własnej psychoanalitycznej terapii mógł znaleźć teoretyczne podstawy. „Wydaje mi się słuszne, że Freud wszelką twórczość uważa za przekształcenie i uwznioślenie instynktu rozrodczego [...]”, że „w erotyzmie właśnie szuka zalążka i motoru prawie wszystkich «wyższych» przeżyć indywiduum [...]”. Ślady tego przekonania znaleźć można nawet w teorii sztuki Witkacego. Perwersja („Nie tak ...”) i nienasycenie („za mało było ust” - to z Jedynego wyjścia), te pojęcia z fizjologii Istnienia Poszczególnego, dostały się do jego estetyki jako teza o formalnej perwersji i o nienasyceniu formą w sztuce współczesnej. Opis malowania obrazu w Jedynym wyjściu obfituje w określenia zmysłowe, erotyczne, perwersyjne: „skulminowane napięcie kierunkowe, jak sztych w brzuch od spodu, pieniło się fontanną

90 Malinowski, który czytając powieść przyjaciela, znał tylko pierwsze zakończenie, zauważa, że nie zawiera „das erlösende Wort”. B. Malinowski, Dziennik..., s. 210.

91 S.I. Witkiewicz, Narkotyki - Niemyte dusze, s. 221-222, 132, 221, 220 (kolejne cytaty w tym rozdziale, s. 29). 
wytrysków ku górze, gdzie cynober, w gradacjach aż do czystej bieli, wlewał się roztopioną miazgą $\mathrm{w}$ zwał ultramaryny [...] W ten punkt wwiercał się teraz z cienkiego włosia pędzelek Marcelego”. „...kondensował cynobry natężone do pęknięcia wokół masy zionącej zaświatowym jakimś błękitem ultramaryny ruchami kolistymi małego pędzelka, ruchami, które zostawały zastygłe na obrazie, jak lawa zastygła zachowuje w swym bezruchu kształt erupcji, czyli wyrzygu, który wyrwał ją z wnętrza ziemi: tu gorejącym wnętrzem była cała jego jaźń [...]"92.

Według Brunona Hillebranda, autora prac o estetyce nihilizmu, Nietzsche stworzył nowy model estetyki wyrażającej fizjologię sztuki, jej orgiastyczną, organiczną funkcję. „To całkowicie nowa estetyka, wedle której sztuka czerpie uprawomocnienie z życia, a nie z jakiegoś duchowego ideału - sztuka jest zjawiskiem potęgowania życia w czystej immanencji. Rausz tworzenia to nic innego jak akt seksualny"93. Błoński, pisząc o młodym Witkacym, cytuje zdanie z Psychologii sztuki Nietzschego drukowanej w „Chimerze” w 1902 roku, jakże bliskie zmysłowemu słownictwu Witkacego: Sztuka „przypomina stany animalnego wigoru, jest ona w gruncie rzeczy nadmiarem i wytryskiem kwitnącej cielesności w świat obrazów i pożądań" 94 .

I w sztuce, i w teorii Witkacy jest bardzo bliski Nietzscheańskiemu postulatowi sztuki zmysłowej, orgiastycznej. Estetyka Czystej Formy wywodzi się z założenia psychofizycznej struktury osobowości, mówi o psychice i fizjologii, o immanencji, a nie o transcendentnej idei piękna; zasada ,jedności w wielości” ujmuje wprawdzie całe Istnienia i wykracza poza jednostkę, spełnia się nie w „człowieku w ogóle”, lecz całkiem konkretnie wewnątrz poszczególnej osoby.

Jeden rodzaj tekstu Witkacego nie wystarczy, aby uchwycić złożoność jego koncepcji sztuki. Trzeba spojrzeć na nią z różnych perspektyw, które czytelnikom proponował jako filozof i jako artysta. Teksty Witkacego wzajemnie się uzupełniają, w pewnym sensie są niesamodzielne. Pierwszy zawiera wykład Czystej Formy, sporządzony dla naukowego, teoretycznego dyskursu, to tekst „oficjalny”, ujmuje psychofizyczność sztuki w ramach opisu bytu - od podstawowych pojęć systemu filozoficznego autora po szczegółowe zasady kompozycji i ujęcia formy. Drugi to opis dokonany przez praktyka na podstawie introspekcji podczas procesu twórczego - takim jest zapis odczuć malarza podczas orgiastycznego malowania obrazu w Jedynym wyjściu; przedstawia napięcie sprzecznych

92 Tenże, Jedyne wyjście, s. 162, 167.

${ }_{93}$ B. Hillebrand, Ästhetik des Augenblicks, s. 8; F. Nietzsche, Kritische Studienausgabe in 15 Bänden, München 1980, Band 13, s. 299.

${ }_{94}$ Cyt. wg J. Błońskiego, Od Stasia do Witkacego, Kraków 1997, s. 64.

Wojciech Sztaba


uczuć i myśli w momencie doświadczenia metafizycznego „takości” i jego rozładowanie w sztuce, jak w akcie seksualnym. Trzeci dotyczy obrazów, ich pojawiania się w widzu, ich działania. Przykładem jest sprawozdanie $\mathrm{z}$ wizji pod wpływem peyotlu, przedstawia nie teorię i psychologię sztuki, ale obrazy, ich dziwne, tajemnicze dzianie się, obrazy, w których bierze się udział jak w misterium, jak w rytualnym spektaklu. „Obrazy łączą się $\mathrm{w}$ dziwne sploty $\mathrm{z}$ uczuciami muskularnymi, z czuciami wewnętrznych organów i tak powstaje nie dająca się rozplątać całość, o niesłychanie subtelnym nastroju ogólnym, która wymyka się wszelkiej analizie i rozsypuje się w gruzy, w nieokreślony chaos przy najmniejszym wysiłku w celu jej skonsolidowania"95. Czwartym tekstem są jego obrazy, dramaty i powieści, a w nich te napięcia, o których mowa w innych tekstach i które teraz dostępne są bezpośrednio odbiorcy.

\section{Sztuka z nicością w tle}

Kiedy nic nie ma - albo kiedy jest tylko nic, sztuka staje się schronieniem, ratunkiem przed zwątpieniem. Wpadli na to romantycy, podkreślał to Nietzsche: nie ma sztuki pesymistycznej, sztuka zawsze potwierdza. Ale czy każda sztuka przynosi zbawienie? Około 1900 roku, w czasie „przewartościowania wartości” - nowa, zupełnie inna sztuka ma wyraźny bonus wobec tradycyjnej, akademickiej, której praktyki i teorie doprowadziły poniekąd do kryzysu. Fronty sensu i bezsensu, istotności i błahości biegną przez środek sztuki, być artystą, znaczy również wybrać, opowiedzieć się po jakiejś stronie. Droga do ratunku przez wyemancypowaną sztukę przypomina niebezpieczną wyprawę po świętego Grala, próbę talentu i charakteru, pełną przeszkód i pułapek, takich jak „dobre rady” profesorów Akademii: „Niech pan dwa lata nic nie myśli i stara się jedynie opanować formę"96. A jeśli talentu nie starczy? Lub postawi się na niewłaściwą sztukę, której nikt nie będzie chciał oglądać? W możliwości ratunku tkwi pułapka, straszy widmo porażki, ciągle nowych konfliktów - ze sobą, sztuką i społeczeństwem.

Wyobrażenie Bunga o własnej sztuce jest „mgławicowym” przeczuciem jej kształtu, na pewno dalekiego od realizmu. Świat, przedmioty, życie mają dostarczać tylko surowca dla dekoracyjnych kompozycji. Wszystko, co ważne, ma dziać się między tonami, kolorami i kształtami, które odgrywają formalne, a nie zaledwie życiowe, komedie i tragedie.

95 S.I. Witkiewicz, Narkotyki - Niemyte dusze, s. 122.

96 Tenże, 622 upadki Bunga..., s. 89. 
Lecz zamiast próbować tworzyć takie właśnie obrazy, Bungo rysuje „potwory”, „demoniczne kompozycje” à la Rops, Munch i Kubin, ponure, pesymistyczne i pokrętne przedstawienia dręczaccych się wzajemnie ludzi. Do nich należy sam młody artysta i jego podstawowy konflikt: $\mathrm{z}$ jednej strony dąży (w teorii przynajmniej, w której łatwo rozpoznać można zapowiedź teorii Czystej Formy) do sztuki dekoracyjnej, formalnej, „czystej sztuki”, jak ją nazywa. Z drugiej zaś strony pociąga go rysowanie scen wyrażających psychiczne, jak najbardziej życiowe problemy. Tłumaczy się tym, że „ta twórczość ma być usprawiedliwieniem artystycznym upadków życiowych, a nie istotną twórczością"97.

Mimo że bez całkowitego przekonania i w konflikcie $\mathrm{z}$ własnym ideałem sztuki czystej, Bungo realizuje w rysunkach nihilistyczny program estetyki brzydoty, jak robił to sam Witkacy we własnej sztuce, w „brzydkim rysunku”98. „Potwory” Bunga i Witkacego są odmową udziału w mieszczańskiej sztuce, w tym, co nie ma wartości, co jest skompromitowane, co jest gładkim, obłudnym, sentymentalnym obrazowaniem, które musi zostać oczyszczone do „nicości”. Lata później „prawdziwe”, fantastyczne potwory wejda do jego malarstwa, rysunku i teatru, być może symbolizując przełamaną groteską ślepą siłę woli. Wtedy Witkacy znajdzie także w swojej teorii nieco zawiłą formułe dopuszczająca „potwory” do sztuki Czystej Formy: treści życiowe (a do nich należy „potworowatość”) są jej koniecznym, choć nieistotnym elementem.

Nową sztukę spotyka Bungo w Paryżu. Nie obrazy Gauguina, a innego artysty, Fagassa, „potwora dekoracyjnej sztuki”, wywołują u niego estetyczny wstrząs ${ }^{99}$. Jest zaskoczony i wzburzony gwałtownym, dzikim malarstwem, które nie zadowala się zastygłą, skamieniałą harmonią form dekoracyjnej kompozycji, lecz dąży ku jej odwrotności, chce wyrazić to, czego wyrazić się nie da, i to wraz z całą tego niemożliwością, poza realizmem, dekoracją i płaszczyzną - na granicy szaleństwa. „Czy ja wiem, jak to wyraziç"?, przyznaje Bungo. To sztuka, która nie dąży do harmonii form i barw, do balansu, równowagi, lecz sztuka agresywna, zmysłowa. Formy na obrazach „zdawały się tryskać niesamowitym, ciemnym żarem”, „seledynowe kobiety [...] tarzały się w jakiejś miazdze fioletowo-czerwonej [...], ciała tańczyły wśród purpurowych palm”, a poszarpane kolory kąsały się ze sobą. Wyraźnie brzmi w tym opisie echo Nietzscheańskiej orgiastycznej sztuki, zafascynowany Bungo jest wobec niej bezradny. Zdaje sobie sprawę z tego, że droga radykalnych decyzji

97 Tamże, s. 417.

98 Zob. W. Sztaba, Gra ze sztuką. O twórczości Stanisława Ignacego Witkiewicza, Kraków 1982.

99 S.I. Witkiewicz, 622 upadki Bunga ..., s. 136-141.

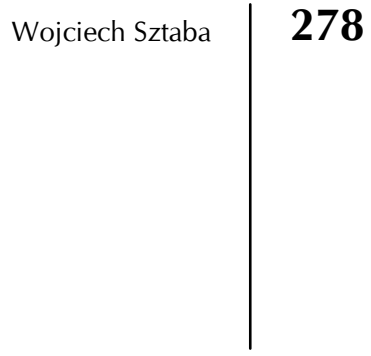


artystycznych jest przed nim zamknięta. „Ja nigdy nic podobnego nie zrobię, nie będę się starał. Ja zostanę na płaszczyźnie”.

Paryski epizod przynoszacy objawienie nowego malarstwa nie ma w powieści dalszego ciągu. A jeśli, to negatywny, gdyż właśnie od tego spotkania ze sztuką „niemożliwą” zaczyna się początek końca sztuki Bunga. Sztuka nie ratuje go. Czy dlatego, że nie był ze sobą w zgodzie? Ostatnia próba, która podejmuje przed samobójstwem, jest niedopowiedzeniem, urwanym zdaniem: pół ślepy rysuje kredkami obrazki na małych karteczkach - ,jak dziecko”. Jak wyglądały te jego ostatnie dzieła? Czy były dziecięce co do formy, czy co do treści? Czy były wyrazem rezygnacji z "wielkiej sztuki”, czy próbą zaczęcia od nowa, od dziecięcej wyobraźni? Na początku powieści Bungo wspomina w swoim Utworze siostrę Anzelmę: „niech zapłaczę raz jeszcze nad twymi nieudolnymi bohomazami, w których jest alfa i omega twórczości"100. Czy miały to być rysunkowe „potwory” Witkacego?

„Trzeba mieć chaos w sobie, żeby zrodzić gwiazdę" - cytuje kiedyś Bungo Nietzschego. Nie udało się.

\section{Sposób na formę: kłąb}

Raz po raz pojawia się w tekstach Witkacego słowo kłąb, spokrewnione $\mathrm{z}$ węzłowiskiem i splataniem. W teorii teatru jest mowa o „węzłach sit rozłożonych w czasie stawania się sztuki na scenie"101, które oznaczają miejsca szczególnie akcentowane w partyturze dramatu, gdzie wzmagają się „napięcia dynamiczne” scenicznego dziania.

Pojęcia „węzłowiska” używa Witkacy w kontekście psychoanalizy, określa nim kompleks „bezwyjściowych pozornie zawikłań”, „plątowiska, bagna [...] i potworowiska podświadomych głębin"102. Z psychoanalityczną konotacją gości ten termin często w jego utworach literackich: „Nierozplątany kłąb szalonych myśli wirował mu w głowie”103. „Kłębi się coś na samym dnie mojej istoty”, jakiś „perwersyjny węzeł sił mogących rozsadzić całą naszą przyszłość i pogrążyć świat w anarchii”104. „Kłąb dziwnego stanu, samego $\mathrm{w}$ sobie, nieobjawionego jeszcze zabarwieniem żadnego rzeczywistego kompleksu, wybuchał jakby z samego dna istoty osobowości i chwiał się w nieokreślonym bliżej wymiarze ducha, zanim spadł na jakiś inny stan konkretny lub na coś dziejącego się w zewnętrz-

100 Tamże, s. 56.

101 S.I. Witkiewicz, Teatr, s. 342.

102 Tenże, Narkotyki - Niemyte dusze, s. 227; Freud używa w Traumdeutung (1899) pojęcia punktu węzłowego we śnie, gdzie spotykają się liczne wątki myślowe.

103 S.I. Witkiewicz, 622 upadki Bunga..., s. 350.

104 Tenże, Dramaty, t. III, s. 261, 329. 
nym świecie"105. Krótko mówiąc, w stylu piosenek porannych Witkacego: „I przez ohydny swój niezupeł/Zawiązał on ten straszny supeł”106. Z tych indywidualnych węzłowisk stworzony jest tłum, „splątane wężowisko rozszalałych gadów"107, grupa, masa psychofizyczna - obiekt Witkacowskiej obserwacji: ,jedyna jeszcze forma twórczości dzisiaj: potrafić wedle własnej woli i fantazji zakręcić porządnie kłębowiskiem ludzkim"108.

Sztuka jest polem szczególnego skłębienia. Obraz malowany przez Marcelego w Jedynym wyjściu to „Kłąb potencjalnej siły jak w niewybuchniętej bombie”. Marceli „wiedział, że żyje tylko w tym nierozwikłanym a prężnym i niecierpliwym [...] kłębowisku barw i linii”. Stojąc przed obrazem, „Marceli skłębił się w sobie z paletą w ręku i pękiem pędzli, jak gad nie z tej planety”. „[...] mąt rwących się w nieskończoność form ryczał obłędem"109.

Jest w tym pojęciu siła, która czerpie energię ze wszystkich znajdujących się w stanie permanentnego skłębienia tekstów i obrazów Witkacego. To ta sama siła, która nadawał słowu, kiedy staje się ono elementem artystycznym, kiedy nie tylko oznacza „cos”, lecz prowadzi własną grę, naładowane szczególnym napięciem poprzez brzmienie, przez asocjacje i obrazy.

Kłąb czy węzłowisko jest figurą interpretacyjną, pomocniczą, stworzoną na użytek czytania i oglądania sztuki Witkacego, jego obrazów, sztuk teatralnych i powieści; figura to wprawdzie nieprecyzyjna, lecz ukazująca te właściwości sztuki Witkacego, które nie są może dostępne innej metodzie. To skrót, ikona, symbol dramatycznej zasady twórczości Witkacego ${ }^{110}$ zrodzony z myśli o sprzeczności Istnienia, o ciągłej oscylacji pomiędzy stanami, myślami, uczuciami, o podwójnym znaczeniu Nicości jako tej, która jest możliwością, miejscem dla pojmowania bytu i tej, która pochłania i niszczy tych, co tej szansy nie widzą. Nad jej bezdenną przepaścią odbywa się ten taniec kłębowiska. „I nastąpiła jedna z tych szalonych nocy [...] gdzieś już w otchłaniach Absolutnej Nicości"111.

Pierwszy projekt kłębu naszkicowany został w 622 upadkach Bunga, gdzie, parafrazując Błońskiego, następuje „zawęźlenie konfliktu”, pierwszy węzeł sił w całej Witkacowskiej twórczości, w której wiele katastrof,

105 Tenże, Pożegnanie jesieni, s. 42-43.

106 Tenże, Jedyne wyjście, s. 59.

107 Tenże, Dramaty, t. I, s. 456.

108 S.I. Witkiewicz, Dzieła zebrane, t. 3: Nienasycenie, opracowali J. Degler, L. Sokół, notą wydawniczą opatrzył J. Degler, Warszawa 1992, s. 369.

109 Tenże, Jedyne wyjście, s. 130, 94, 139, 150.

110 Węzeł jest motywem istotnym dla ikonosfery około 1900, ,jako obraz przeplatania się bytu, poznania i sztuki”. R. Sorg, Aus den „Gärten der Zeichen”. Zu Carl Einsteins „Bebuquin”, München 1998, s. 181.

111 S.I. Witkiewicz, Pożegnanie jesieni, s. 259. 
wiele apokalips, zostanie wpakowanych w jedną ${ }^{112}$. Postacie kłębią się na scenie, w powieściach, w malarstwie i rysunkach, kłębi się to, co myślą, czego pragną, pożądają, w kółko, od początku i bez końca, w „ogólnym zamieszaniu”, w jakimś potwornym węźle samozapępiajacych się gnębitów, i jeśli nie jako rzeczywisty „węzeł ludzki”, jaki tworzą Mandelbaumy w Nadobnisiach i koczkodanach, postacie w scenach grupowych w Matce, w Macieju Korbowie, w Wariacie i zakonnicy czy w powieściach (spektakl teatru Kwintofrona Wieczorowicza w Nienasyceniu) - to jako psychiczna szamotanina Istot Poszczególnych i ich skupisk snujących zawiłe, spekulatywne kombinacje złożone $\mathrm{z}$ idei filozoficznych, życiowych pragnień i popędów, z blagi i pretensji. Kłąb dyszy nienasyceniem, wyraża paniczne poszukiwania sensu wobec nudy i nicości, toczy się po scenie niczym ogromny gniot, wór łachmanów, napędzany żądaniem natychmiastowego spełnienia i zbawienia przez niedostępne, na horyzoncie majaczące, i ciągle oczekiwane uczucie metafizyczne. Cała ikonosfera Witkacego wplatała się w ten kłąb, wszystkie jej nitki i osnowy. I każdy wątek posiada własne napięcie - jak walka płci, seks, pragnienie władzy, sadyzm i masochizm. Przewala się to kłębowisko raz w jedną, raz w drugą stronę, wciąż coś innego jest na górze, powiązane sznurkami, skrępowane (jak Bungo w swoich snach), wierzch i podszewka, to i tego odwrotność, a wszystko otulone w nicość. Zagubienie, nic, strach i nuda, i szukanie sposobów, wymyślanie pokrętnych strategii, głupota i nieprzytomność. Kłąb jest maniakalny, natrętny, ciągle w upadku, czasem z orgazmem po drodze, chwilo trwaj - ale czy to sa te wymarzone, wieczne powroty? Nie jest to dionizyjsko upojny taniec, a pijackie, narkotyczne zataczanie się i potykanie tuż na krawędzi sceny, „ruchoma projekcja na ekranie próżni bez dna"113.

Czy myśl o Czystej Formie, o koniecznej niezależności sztuki od życia, nie jest odpowiedzią na zmęczenie kłębowiskiem? Chaos jest wszechobecny w obrazach Witkacego, nawet w wylizanych portretach wygląda spoza pleców modeli. To właśnie Czysta Forma układa go w zagmatwaną, ale uporządkowaną całość, w jej ramach kłąb zostaje spętany, ujarzmiony, staje się znakiem Jedności w wielości. W ten sposób forma, koniecznie czysta, tryumfuje nad życiem, pozornie od niego daleka, żywi się jednak jego treścią i odczuwana jest w całej życiowej konkretności odczuć, także tych wewnętrznych, muskularnych.

112 Zawęźlenie konfliktu jest tytułem rozdziału w książce Jana Błońskiego Od Stasia do Witkacego; O wielości katastrof: J. Błoński, Trzy apokalipsy w jednej.

113 S.I. Witkiewicz, Dramaty, t. III, s. 581. 
O tych dwóch światach egzystujących obok siebie i wzajemnie się przeplatających mógł Witkacy przeczytać u Schopenhauera i dopasować jego koncepcje do własnego myślenia o świecie i sztuce: świat woli kierowany siłą ciągle od nowa realizującego się gatunku to właśnie kłębowisko, Tummelplatz, miejsce cierpienia w życiu, natomiast świat wyobrażenia oferuje „przedstawienie godne oglądania” i jest miejscem doznania estetycznego ${ }^{114}$.

Kłębki wełny w Matce to Barthes'owskie punctum, szczegół wyrażający metaforę nitki i kłębka, miejsce, które zwraca uwagę, zobaczone „poza kolejką" akademickiej interpretacji i od którego można zacząć myśleć o całym teatrze Witkacego. Na tle czarno-białej dekoracji, która przemienia scenę teatralną w czarno-białą projekcję filmową albo w fotografię, „jedyną rzeczą kolorową jest robótka włóczkowa, którą robi Matka - mogą być kolory: niebieski, różowy, żółty i jasnopomarańczowy" - podkreśla w didaskaliach Witkacy. Od drugiego aktu i te kolory znikają, robótka jest teraz jasnobrązowa, jak na odbitce w sepii. Jakby myślał o „robótce” z przedmowy Strindberga do Gry snów, gdzie „Wszystko może się wydarzyć, wszystko jest możliwe i prawdopodobne. Czas i miejsce nie istnieją. $\mathrm{Na}$ błahej podstawie rzeczywistości fantazja snuje i tka nowe wzory"115.

$*$

Tadeusz Kantor na swój sposób doskonale wyraził, o co chodzi w skłębieniu Witkacowskiej formy. Oto fragment jego Partytury do sztuki W matym dworku:

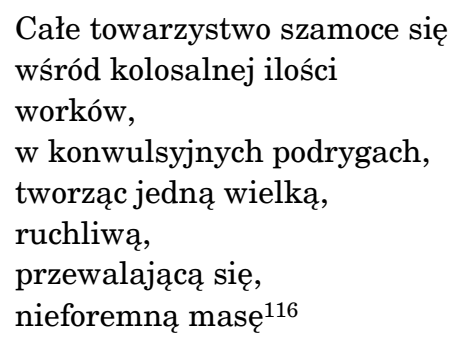

Zdanie Kantora: „Witkiewicza uważam za prekursora informelu”, mogłoby służyć za motto do tekstu o malarskim teatrze opisanym w Jedynym wyjściu.

114 A. Schopenhauer, Zur Metaphysik des Schönen und Ästhetik (Parerga und Paralipomena II), [w:] Werke, Band X, s. 418.

115 A. Strindberg, Gra snów, [w:] tenże, Wybór dramatów, wybór, przekład i przypisy Z. Łanowski, wstęp L. Sokół, Wrocław-Warszawa-Kraków-Gdańsk 1977, s. 733.

116 T. Kantor, Metamorfozy. Teksty o latach 1938-1974, oprac. K. Pleśniarowicz, Kraków 2000, s. 228. 


\section{Świat na opak}

Nicość, ta pochłaniająca, „pogłębia się” w czasie między 622 upadkami Bunga a napisaną w 1918 roku sztuką Maciej Korbowa i Bellatrix. Czy pierwsza sztuka Witkacego jest psychodramą odtwarzającą traumę wywołaną samobójstwem narzeczonej i udziałem w wojnie?

W dramacie przedstawione jest zabójstwo młodej kobiety, poświęconej (za jej przyzwoleniem) przez grupę nihilistów opętanych nicością, po to, by spowodować „odwrotność najgłębszej istoty” tytułowego bohatera Macieja Korbowy... A co jest istotą Macieja Korbowy? Nicość... ta przed początkiem i po końcu jego przypadkowego pojawienia się w kosmosie. Ale jak śmierć młodej kobiety może spowodować odwrócenie Nicości? Czy przez wampiryzm? Czy przez podglądanie „stającej się Nicości” i odczuwanie najwyższego napięcia, jakim jest sadystycznie przedłużane przejście do śmierci? Miałaby to być odpowiedź na niepokojące pytanie Lecha Sokoła o Istnienie Poszczególne jako dzieło sztuki117, którego formę da się „kombinować” aż do ostateczności? „Czarna msza” w Macieju Korbowie zapowiada teatr Kwintofrona Wieczorowicza w Nienasyceniu, sataniczny rytuał „targający za trzewia”, celebrujący śmierć i seks na scenie. W dramacie ofiara dokonuje się w kącie kawiarni, wielkie okna wychodzą na ulicę, gdzie szaleje rewolucja, a między oknami wisi lustro, w którym odbijają się jej uczestnicy - kat, ministranci, kapłan i ofiara.

Rozważania o nicości osiągają w Macieju Korbowie stan histerii. Wzrasta panika, gorączkowe poszukiwanie wyjścia za wszelką cenę, może w jakimś ciemnym systemie, jakiejś pseudoreligii, która ma przynieść zbawienie i przenieść na drugą stronę bezsensu. Ta pseudoreligia tajemnej sekty posługuje się hipnozą, sadyzmem, masochizmem i perwersją; jej dogmaty spotykają się z dogmatami rewolucji, z ideologią, terrorem wartości i zbiorową psychozą, które w systemach totalitarnych kierują zachowaniem ludzi.

Tekst podąża za crescendo formy, początkowe „rondo” z Prologu, szalona gonitwa wokół stołu, nadaje tempo całej sztuce. W zamieszaniu i strachu coraz szybciej toczy się kłąb nad przepaścią, coraz głośniejsze, zatrważające dźwięki dochodzą zza sceny, na koniec słychać łomotanie w drzwi. Nieliczne momenty zwolnienia akcji nabierają, przez kontrast, szczególnie mocnego napięcia, jak (na scenie tylko zapowiedziane) oglądanie gwiazd na dachu domu, jeszcze jedno przypomnienie „motywu Pas-

117 „...w jaki sposób człowiek, Istnienie Poszczególne, realizujący Jedność w Wielości, czyli zasadę, która określa dzieło sztuki w Czystej Formie, jest postrzegany przez drugiego człowieka; czy postrzegając inne IP w jego jedności będącej ujęciem wielości, możemy również przeżyć Uczucia Metafizyczne, Tajemnicę Bytu?”. L. Sokół, Witkacy i Strindberg..., s. 350 . 
cala”: „chodź na dach”, mówi Teozoforyk do Cayambe, „tam patrząc na gwiazdy przemyślimy to w pojęciach ścisłych, o czym oni tylko mówią bezładnie. [...] tam jest komin, będziemy jak na okręcie w falach Nicości. Teraz ci powiem ostatnie słowo wiedzy o Nicości"118.

Cóż ci poszukiwacze Tajemnicy Istnienia o niej wiedzą, kiedy o niej „mówią bezładnie”? Co wiedzą o Nicości, o spełnieniu? „Nienasyceni” błądzą i snują się w aurze Nicości, w teatralnej mgle. Powtarzają w kółko te same słowa wciąż w innych kombinacjach, jakby z nadzieją natrafienia na magiczną formułę przepędzającą nudę i strach.

"Odwrotność" zdaje się takim słowem kluczem. Jest pokrętnym sposobem zwalczania nicości, liczącym na to, że dzięki słowu uda się wyrwać $\mathrm{z}$ tego świata, nie lądując $\mathrm{w}$ wyimaginowanych zaświatach. Pomyślane lub wypowiedziane nie tylko wywołuje przyjemne złudzenie przekraczania granic uznawanych za nieprzezwyciężalne i oglądania rzeczy z drugiej strony, lecz jest także zemstą na świecie, a raczej na jego mieszkańcach, niezauważających, że chodzą do góry nogami. Świat na opak to świat sprzeczności, paradoksów, świat przenicowany, w którym Nicość jako podszewka Bytu wychodzi na wierzch. Albo Nuda, jej wierna towarzyszka, która wpycha się na scenę w Szewcach, w sztuce, gdzie wiele jest „na opak”, kurtyna opada, podnosi się i znowu opada, mieszając początek, środek i zakończenie, a didaskalia rywalizują z akcją na scenie. Jak w sztuce Ludwika Tiecka z 1812 roku, której tematem jest teatr „na opak”. Sztukę zaczyna Epilog we własnej osobie: „Jak się wam nasza sztuka podobała?” i kończy Prolog: „Zobaczycie teraz sztukę...”. Aktorzy siedzą na widowni, publiczność gra na scenie wraz z personifikacjami utworów muzycznych, okrętami wojennymi, maszyną do robienia burzy i maszynistą, czyli Deus ex machina. „Nie byłoby lepiej, gdyby takie rzeczy nie zostały napisane?” - pyta Menuetto con Variazioni ${ }^{119}$.

Zagadkami opartymi na odwrotności posługuje się też Maciej Korbowa. „Bardziej obawiam się sztuki niż życia”, mówi na przekór romantycznemu mitowi sztuki ratującej artystę przed jałowością życia. Czy boi się jej jak „diabeł święconej wody”? Pewnie tak - Korbowa prowadzi swoją własną cyniczną grę z Nicością, w której nie ma miejsca na sentymentalne „zbawienie” przez sztukę. A jaki sens ma kolejna zagadka: „muszę najpierw nie być, by potem być"? 120 . Inaczej wprawdzie sformułowana,

118 S.I. Witkiewicz, Dramaty, t. I, s. 122.

${ }^{119}$ Ludwig Tieck, Die verkehrte Welt, Ein historisches Schauspiel in fünf Aufzügen (1812). O motywie świata na opak i odwrotności w kontekście płci pisał obszernie Lech Sokół w: Witkacy i Strindberg..., rozdział Hermafrodyta $i$ androgyne.

120 O tym zdaniu pisał również Lech Sokół w: Witkacy $i$ Strindberg..., s. 350 passim, rozpatrując je w kontekście rytuału wtajemniczenia. 
lecz jest to ta sama zagadka, jaką zadaje Witkiewicz filozof o Istnieniu zaprzeczającym swojej własnej istocie. Tutaj, wypowiedziana przez Korbowę, ma działać jak zaklęcie, które przez odwrotność zapełni Nicość: skoro nasze jednostkowe istnienie jest przypadkowe, bezcelowe, jeśli to tylko błysk w nicości, bez przedtem i potem - to magiczna formuła, „najpierw-nie-być", jest wyzwaniem wobec bezsensownej przypadkowości, wymuszeniem początku poza biologicznym początkiem, niesłychanym żądaniem wieczności dla Istnienia Poszczególnego, jakiegoś „bez-początku" bycia czymś w Niczym. Ale Nicości nie da się zakląć ani słowami, ani ofiarami. Masakra na końcu dramatu jest ostateczną „kombinacją” Nicości w życiu, zapowiedzianą już w scenie morderstwa w kawiarni. Oto, co znaczy doświadczyć nihilizm od środka, zanurzyć się w sadystycznym, bezkarnym czynieniu, w doświadczeniu zła. „Nicość musi być naszym ideałem i musimy jednocześnie być w tej nicości [...]"121. Widzem, reżyserem i autorem tego teatru czy raczej „czarnej mszy” na scenie teatralnej jest Maciej Korbowa.

\section{Piekielny teatr bezimiennej okropności}

Wśród wielu objawień świata pod znakiem Nicości są także obrazy sztuki po końcu sztuki. W Jedynym wyjściu przedstawione jest malarstwo Marcelego Kiziora Buciewicza, ostatniego prawdziwego malarza: malowany na oczach publiczności i czytelnika obraz jest najpewniej ostatnim istotnym okazem tej sztuki w historii malarstwa. W Sonacie Belzebuba przedstawiona jest muzyka, która już tylko w diabelskim wydaniu, jako muzyka Czystego Zła, wydaje się możliwa. W Onych mowa jest o teatrze w formie piorunującej mieszanki okrutnej komedia dell'arte w Czystej Formie z „pure nonsensem”, gdzie na „pierwszej próbie już są trupy". W Nienasyceniu prowadzi nas autor do przenikniętego na wskroś niszczącym nihilizmem teatru Kwintofrona Wieczorowicza, gdzie możemy bliżej zapoznać się ze spektaklem „po końcu teatru” 122 . Na scenie zobaczymy więc to „nie”, o którym Nietzsche pisał, że jest czynione ${ }^{123}$.

Sztuka po końcu sztuki zbudowana jest na ruinach i wspomnieniach tej minionej, istotnej. Wejście do teatru zdobią okazy zdegenerowanej awangardy początku wieku XX, szczególnie sowieckiej, abstrakcyjne bohomazy (biezobrazje), popłuczyny „staropikasowe”, lampiony z wieżow-

121 S.I. Witkiewicz, Dramaty, t. I, s. 102.

122 Opis teatralnego spektaklu: Nienasycenie, s. 259-273.

${ }^{123}$ Friedrich Nietzsche, Jenseits von Gut und Böse, nr 208, gdzie pisze o pesymizmie „der nicht bloß Nein sagt, Nein will, sondern [...] Nein tut” (nie tylko mówi i pragnie Nie, ale czyni Nie). 
ców i części ciał (przypuszczalnie z przedstawieniami genitaliów). Pierwsza kurtyna, jak "Siemiradzkiego” w dawnym (w Nienasyceniu to daleka historia!) teatrze krakowskim, przedstawia „karykaturę Czystej Formy”, druga zasłona, ta co zapadnie po spektaklu, jest czarna. Czarny jest też pokój, z którego wypełza dyrektor tego teatru, Kwintofron Wieczorowicz. Kazimierz Malewicz zaprojektował również kurtynę z czarnym kwadratem (swoim pierwszym) do wystawionej w Petersburgu w 1913 roku opery Zwycięstwo nad stońcem. Ten czarny kwadrat miał być, jak później na obrazach, bramą do sfery czystego odczuwania, początkiem nowego poznania. Natomiast za czarną kurtyną w teatrze z Nienasycenia nie ma już nic, nie ma innego świata, nic się za nią nie chowa, tylko zło panoszy się na scenie, wydobywa emocje z samych „bebechów” publiczności, jego aktorami są perwersja, gwałt, seks i śmierci, jak podczas publicznej egzekucji, jak w rzymskim cyrku.

Ta Nicość to piekło, „przybytek Szatana”, „jedno kłębowisko zwyrodnienia na samej granicy zbrodni”, „nieomal metafizyczne wyuzdanie wywróconej jak rękawiczka rzeczywistości”, „diabelski smar zmysłowości” dla znudzonych i przytępionych widzów, żyjących w świecie poza teatrem w „złowrogiej, niczym nienasyconej nudzie i pospolitości”.

„Diabły paliły na gwałt w płciowych piecach”. Dziwność istnienia zostaje zastąpiona przez „dziwność najrzadszych narkotycznych omamień i najwyuzdańszej dobrowolnej śmierci w sadystycznych torturach, zadawanych przez Nią, jakiegoś wyśnionego kobiecego hiperbelzebuba”. „Każde wymówione słowo było pocałunkiem w zbrodniczym stopniu bezwstydnym i lubieżnym, a jednocześnie świętym, jak dotknięcie jakichś najświętszych relikwii”. Nie ulega wątpliwości, że na scenie odbywa się diabelski rytuał, „czarna msza”, „programowe nabożeństwo na cześć Absolutnej Nędzy Istnienia i jego definitywnej niewyduszalności dla celu rozpędzenia Wielkiej Nudy” [...] „potworna msza szarozielona (koloru suchotniczej flegmy) do nieznanego bóstwa ni to złego ni to dobrego". Nie jedyna to zresztą „czarna msza” w sztukach Witkacego: w tragedii Maciej Korbowa $i$ Bellatrix zarówno zabójstwo młodej Cayambe, jak i masakra w końcowej scenie są rytualnymi ofiarami, wprawdzie bez bóstwa, ale z obsadzonym w roli kapłana Nicości, Maciejem Korbową. Zabójstwo Spiki w Onych i Kurki Wodnej mają również charakter rytualny.

Po zapadnięciu czarnej kurtyny w teatrze Kwintoforowicza zaczyna się w powieści orgia seksu i mordu, życie „zarażone” zostaje perwersyjnym teatrem, historia Genezypa i Persy staje się przedłużeniem narkotycznego, seksualnego ekscesu na scenie: najpierw Genezyp zabija konkurenta młotkiem, potem dusi „w szaleńczej ekstazie rozkoszy” swoją żonę, a generał Kocmołuchowicz spędza ostatnie chwile przed egzekucją

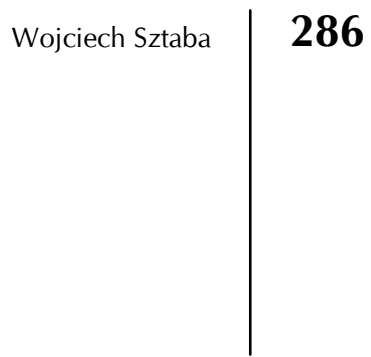


na szalonej orgii ze swą kochanką, która potem, jak oszalała Salome, całuje jego obciętą głowę ${ }^{124}$.

Czarna msza na scenie Witkacego jest parodią supremacji czystego odczucia, uczucia metafizycznego, jest Czystą Formą na opak, „grotesque macabre”, Grande Guignol. Teatr Kwintofrona to „ostatnia placówka szatana w doskonalejącym świecie", gdzie odbywa się nihilistyczny taniec już „nad brzegiem tej przepaści”. Wstrętna „szaro-zieloność” satanicznej mszy jest kolorem jej kolejnej postaci w nowych warunkach, z nijakim bóstwem na ołtarzu, być może jej następnym etapem, wyższym, bo jej dawne wydania to coś operetkowego, kabaretowego, jak w Sonacie Belze$b u b a$. Sataniczny teatr ma tylko jedno zadanie: dać widzom narkotyk, złudną nadzieję wyrwania się z bezwładu nicości, a jedynym jego środkiem jest złapanie publiczności za genitalia, wzbudzenie pożądania, nawet widokiem gwałtu i śmierci.

W tym momencie pojawia się problem, który i Witkacy zauważa: fizjologiczny teatr Kwintofrona zbliża się niebezpiecznie do teorii Czystej Formy u jej psychofizycznej podstawy. Albowiem odczucie jedności w wielości, uczucie metafizyczne, nie jest operacją intelektu, lecz stanem psychofizycznym; napięcia kierunkowe tworzące Czystą Formę nie są wektorami jakiegoś diagramu, lecz są „zakotwiczone” w ciele - w nim odczuwa się formę. W ten właśnie sposób funkcjonuje przecież spektakl na scenie teatru w „Przybytku Szatana” - i to jeszcze jak dobrze funkcjonuje! Tu właśnie fizjologia dyktuje uczucia i myśli, narkotyczna, psychofizyczna, seksualno-perwersyjna gra nienasyconych ciał zwraca się do widzów i wywołuje w nich „to samo nienasycenie”. „Każdy odczuwał te ichnie szprynce i szpryngle w sobie".

Opis spektaklu jest tak sugestywny, tak brawurowy, że nie tak łatwo jest wykazać różnicę ${ }^{125}$. Witkacy stara się ją retorycznie podkreślić, mnoży diabły na scenie, dowodzi, napomina z podniesionym palcem, że brudne życie tworzy brudną, podniecającą, drażniącą zmysły formę, która potęguje „tylko nieznośnie niewiarygodną rzeczywistość zamiast przenosić widzów w inny wymiar" i z prawdziwą, najczystszą formą Czystej Formy nie ma nic wspólnego.

124 Wiktor Grodecki, scenarzysta i reżyser filmowej adaptacji Nienasycenia (2003) przedstawił na końcu filmu dalszy ciąg „czarnej mszy”, niezgodnie wprawdzie z tekstem powieści, ale chyba niedaleko od intencji autora: kat ścina głowę generałowi Kocmochułowiczowi nie na trawniku przed kwaterą chińskiego dowództwa, ale podczas kopulacji z kochanką za podświetlonym parawanem, na oczach zgromadzonych widzów, jak w teatrze cieni. „... na tle tego, co ostatni raz [...] dokonał z kochanką” (Nienasycenie, s. 415).

${ }^{125} \mathrm{O}$ tej bliskości pisze Jan Gondowicz, nazywając spektakl w Nienasyceniu teatrem Brudnej Formy, rewersem Czystej. J. Gondowicz, Paradoks o autorze, s. 145-152. 
Pomiędzy cielesnością Czystej Formy a pornograficzną makabreską leżą rzeczywiście światy. Czysta Forma nie jest produktem intelektu, ale nie jest też czystą cielesnością ${ }^{126}$. Sztuka nie może konkurować z pornografią, z live-show na scenie. Jaką szansę ma Czysta Forma z jej wysublimowanymi uczuciami metafizycznymi, jej oświecony, aktywny nihilizm w bezpośredniej konfrontacji z „czynionym” i celebrowanym na scenie nihilizmem? To pytanie musi się pojawić w czasie lektury, jest wpisane $\mathrm{w}$ ten moralitet, którego autor nie bez fascynacji i przerażenia, a czytelnik razem z nim, nie mogą oderwać wzroku od spełniającej się oto przepowiedni upadku.

\section{Ikonografia Nicości}

Jak pokazać, jak oddać nic w sztuce? W słowach można Nicość opisać, słowo samo nic nie waży, to flatus vocis, dech zaledwie, ale jak przedstawić ją na obrazie, z jego materialnością 127 ?

Najprostszy sposób malarzy, stosowany od dawna, to założyć tło obrazu czernią. Symboliczność tej czerni-nicości dotyka uniwersalnego, bezpośredniego i zawsze aktualnego przeżycia - oglądania nieskończonej przestrzeni na nocnym niebie. Respekt i lęk przed brakiem światła, przed nocą, chronią obraz czerni przed banałem, przed umownością takiego czy innego znaku. Pomyślmy o czarnych tłach na obrazach Grünewalda, Caravaggia, George'a de Latoura i Rembrandta. Czerń nie jest po prostu atrybutem, jednym z obiektów w rekwizytorni artystów, jako tło zamyka i otwiera przestrzeń obrazu.

$*$

Na okładce książki Conan Doyle’a Firma Girdlestone młoda kobieta siedzi na krześle przed stojącym przed nią starszym mężczyzną, wyraźnie jej zagrażającym. Okładka wedle projektu Artura Horowicza zainspirowała Witkacego do serii zdjęć wykonanych przez Józefa Głogowskiego,

126 Witkacy mówi o tym wyraźnie: żadnych sentymentów, bebechowatości. Stąd jego niechęć do muzyki wokalnej: „Śpiew nie może być abstrakcyjny, to jest krzyk samego ciała i dlatego mówi tylko o uczuciach, nie mogąc dać nam zupełnie innego wymiaru, który nazwałbym metafizycznym, w przeżywaniu siebie". S.I. Witkiewicz, 622 upadki Bunga..., s. 168.

${ }_{127}$ W książce o młodopolskiej recepcji Schopenhauera Jan Tuczyński, Schopenhauer a Młoda Polska, podaje szereg motywów obrazowania poetyckiego, które mogą również odnosić się do ikonografii nihilizmu, jak np. monotonia, wahadłowa rytmika czasu, morze, fala, czarna woda, błąkający się okręt, skwar południa, strumień czasu, samotne, umierające drzewa czy demoniczna kobieta. 
przedstawiającej fotograficzną inscenizację historii o starszym panu demonizującym młodą kobietę 128 .

W tle fotografowanej scenki widać czarną kotarę, powtarzającą motyw czarnego prostokąta z okładki. Prostokąt nie wypełnia w granej scenie całego kadru, postacie wychodzą poza jego boki. Jest to efekt często stosowany przez grafików i w ten sposób posłużył się nim także Horowicz: prostokąt czy inna, mniej lub bardziej regularna, płaska forma w tle, wzmacnia odczucie przestrzenności obrazu, „wypycha” je do przodu, niejako odwrotnie do efektu w obrazach kubistów, którzy wprowadzali płaskie formy na pierwszym planie (litery, fragmenty gazet), by jako „repoussoir” kierowały wzrok widza w głąb obrazu. Efekt „wychodzenia” figury poza tło nie jest zresztą nowym wynalazkiem, stosowali go malarze ilustracji w średniowiecznych książkach, pozwalając postaciom wykraczać poza malowane ramy. Witkacy, który tak wiele wagi przywiązywał do sprawy napięć między płaskimi formami (zob. jego wykład o działaniu przestrzennym płaskich elementów kompozycji w książce Nowe formy $w$ malarstwie), mógł zastosować $\mathrm{w}$ inscenizowanej z Głogowskim fotografii ten prosty i skuteczny środek budowy obrazu.

Interpretację czarnego prostokąta da się prowadzić dalej. Zanim Kazimierz Malewicz namalował czarny kwadrat na białym tle (1914-1915), Lawrence Sterne umieścił go w powieści Życie $i$ myśli J.W. Pana Tristram Shandy (London, 1765-1769). To słynna czarna kartka, czarna dziura, która następuje zaraz po relacji o śmierci Yoricka: „a potem zamknął oczy, aby już nigdy ich nie otworzyć... O, biedny Yoricku”. A jeszcze wcześniej pojawia się u Roberta Fludda w jego dziele wydanym w 1617 roku: Utriusque cosmi maioris scilicet et minoris metaphysica, physica atque technica historia - czarny kwadrat z napisem u każdego boku: „Et sic in infinitum” (i tak w nieskończoność). „Czarne dziury” Sterne'a, Fludda i Malewicza są drzwiami do Nicości, choć położone są na przeciwległych ścianach wnętrza monady. U Sterne'a wychodzą na Nic po końcu (Sterne był jednym z ulubionych pisarzy Schopenhauera), u Fludda na nieskończoność, u Malewicza na Nic, na „pustynię», gdzie dociera do nas tylko odczucie"129. Zadziwiające, ile kierunków może mieć Nicość.

Czy czarne tło za pantomimiczną scenką na fotografiach wedle powieści Conan Doyle'a oznaczać może czarną dziurę, jak u Sterne'a? Groteskowy „bal maskowy” na tle nicości - to byłby ciekawy pomysł reżyserski Witkacego.

128 Powieść Conan Doyle’a (The Firm of Girdlestone) ukazała się w przekładzie Jana Zawirskiego, t. I-III, wyszła jako numery 612-614 Biblioteki Groszowej w roku 1928 (według informacji Janusza Deglera i Jana Gondowicza).

129 K. Malewicz, Suprematyzm (1922-1927), [w:] Artyści o sztuce. Od van Gogha do Picassa, wybrały i opracowały E. Grabska, H. Morawska, Warszawa 1969, s. 353. 
Większość scen w powieściach i w dramatach Witkacego dzieje się w mroku, w ciemności i w nocy, zwiastujących nicość. Bywa, że całe pomieszczenia są czarne. W Macieju Korbowie i Bellatrix pokój w pierwszej scenie wybity jest czarnym suknem, nakryty jest nim również stół, a i krzesła mają czarne obicia. „Zionące ciemnością” drzwi w Pragmatystach prowadzą donikąd130. Czarne ściany występują w scenografii do Guybala Wahazara, Mątwy i do Matki. W śnieżnobiałym pokoju w Tumoru Mózgowiczu stoi czarna tablica, czarny prostokąt na białym tle, na której kredą wypisane są formuły matematyczne. Tablica odgrywa nie tylko rolę rekwizytu scenicznego, ale jest również miejscem przecięcia się dwu przestrzeni, białej, empirycznej pokoju dziecięcego i otwartej w nieskończoność czarnej dziury, której moc demonstrują abstrakcyjne znaczki. Podobną równoczesną obecność dwu przestrzeni demonstruje czarny kwadrat Malewicza.

Czasem, jak zaznacza w didaskaliach do dramatów, nawet światło dzienne nie dochodzi do wnętrz. Na rysunku z projektem scenografii do Nowego wyzwolenia zaznacza: „Okien nie ma”. Nie ma być ich też w scenach dramatów Guybal Wahazar, Kurka Wodna, Nadobnisie i koczkodany, Janulka, córka Fizdejki, Matka, gdzie brak także drzwi; w Mątwie jest wprawdzie okno, ale dochodzi przez nie czerwony blask z ,innego świata". Światło, dzienne czy sztuczne, pojawia się i gaśnie, starannie inscenizowane. „Światełko proszę zgasić i tamte świeczki też" - słychać głos w Janulce. Sztucznym, zimnym światłem lampy łukowej rozpoczyna się Maciej Korbowa, zastąpione potem słabym światłem czerwonej lampki na stole, by z kolei ustąpić nikłej, niebieskiej poświacie wstającego dnia. W zakończeniu sztuki kolejność będzie odwrotna: „Scena ostatnia (jak pierwsza) zaczyna się od czerwonego półmroku, by potem, w scenie finałowej katastrofy, rozświetlić się rażącym światłem”. W tejże sztuce scena widoczna w półmroku, w blasku ognia na kominku, nagle zostaje rozjaśniona światłem elektrycznym i dwie przestrzenie, ciemna i jasna, nagle, boleśnie na siebie trafiają. Janulka, córka Fizdejki: „Słońce poranne zalewa scenę [...] Słońce nagle gaśnie. Na scenie jest prawie zupełnie ciemno [...] Potem ciemności nabierają koloru buroczerwonawego". Wariat $i$ zakonnica: „Oślepiające błękitne światło, puszczone z góry reflektora, oświetla scenę. Lampa górna gaśnie i w ostrym eliptycznym kręgu świetlnym widać tylko kotłującą się miazgę ciał". Nowe wyzwolenie: „Gaśnie światło w drugiej części sali i scena na froncie rysuje się na tle ciemnego wnętrza z daleko większą wyrazistością”. Oni: „W saloniku jest

130 Także w Grze snów Strindberga znajdują się drzwi, za którymi jest: „Nic! Oto rozwiązanie zagadki tego świata".

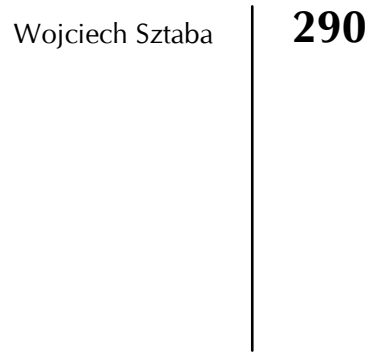


ciemnawo w stosunku do oświetlenia sali”. Trzy kolejne akty Mister Price'a: „Gwiaździste niebo [...] noc [...] rażący blask dnia”.

W Matce czerń jest szczególnie „rozegrana”. Cała scenografia utrzymana jest $\mathrm{w}$ tonacji czarno-białej, jak na fotografii, w innym wymiarze, między światem a Nicością, gdzie przebywają czarno-biali, upiorni ludzie - zombie. Ostatni akt odbywa się w czarnym pomieszczeniu bez drzwi i okien, być może przedstawiając celę w domu wariatów albo raczej model monady Leibniza od wewnątrz, monady otoczonej i wypełnionej czernią, oglądającej nie świat, ale wyobrażone o nim obrazy. Nagle zasłona w tyle sceny otwiera się na wiosenny widok z górami, krótka projekcja dawnego wspomnienia świata na ekranie monady rozświetla na chwilę scenę; po chwili znowu następuje ciemność.

Światło i brak światła. Światło jest jednym z najistotniejszych środków dramaturgii Witkacego: gra jego natężeniem, kolorem, raz białe, raz niebieskie, raz czerwone, jest i zielone: pali się na kominku w Nadobnisiach $i$ koczkodanach, a blask tego ognia "staje się wprost oślepiający" może nie z naszego świata? W nocy, po katastrofie „szalonej lokomotywy”, białe od światła księżyca obłoki płyną po niebie. Człowiek w przypowieści Nietzschego szuka Boga z latarnią w ręku w biały dzień na rynku. „Czyż nie słyszeliście o tym szalonym człowieku, który w jasne przedpołudnie zapalił latarnię, biegał po rynku i bez przerwy wołał: «Szukam Boga! Szukam Boga!»"131. Lampa łukowa, która oświetla scenę w Macieju Korbowie, była w czasie pisania dramatu najsilniejszą lampą elektryczną. Im mocniejsze światło, tym ciemniejsza noc. Bałandaszek, brnąc ku tragicznemu finałowi, zaprzepaściwszy miłość, sztukę i siebie, woła: „A mnie się chce dziś czarnej, czarnej jak Nicość kobiety!"132.

Ale może też być Nicość bez czerni. Witkacy wynajduje na to niezwykłe obrazy. Podobnie jak Malewicz, dla którego „pustynia” była synonimem Nicości i czarnego kwadratu, Witkacy umiejscawia ostatni akt Metafizyki dwugtowego cielęcia na niemal Beckettowskiej pustej scenie z budką telefoniczną pośrodku. W Macieju Korbowie i Bellatrix ukrywa obrazową szaradę, którą najpierw trzeba dostrzec, by móc ją rozwiązać: Wnętrze kawiarni. Dwa duże okna wychodzą na ulicę. Między nimi wisi lustro, pewnie duże, w którym odbija się wnętrze i przebywające tam osoby. Z ulicy dochodzą odgłosy zamieszek, wystrzały, krzyki, przez okna widać biegnące na ulicy postaci. Również w kawiarni zdarzenia są coraz bardziej dramatyczne, młoda kobieta zostaje zamordowana. Cała grupa,

131 F. Nietzsche, Wiedza radosna (1882), § 125: Habt ihr nicht von jenem tollen Menschen gehört, der am hellen Vormittag eine Laterne anzündete, auf den Markt lief und unaufhörlich schrie: „Ich suche Gott! Ich suche Gott!”.

132 S.I. Witkiewicz, Dramaty, t. I, s. 455. 
oprócz jednej osoby, ucieka przez ukryte drzwi w murze między oknami, pod lustrem ${ }^{133}$. Znikają w ścianie, za którą nie ma żadnego pomieszczenia ani miejsca na schody, tylko ulica. Więc dokąd właściwie uciekają? Donikąd? Można sobie wyobrazić, że na moment, nim wejdą w otwór, w przedsionek Nicości, ich postacie odbijają się jeszcze w lustrze. Ostateczna zagłada czeka w następnym akcie, kiedy zginą z rąk Marynarzy Śmierci.

*

Czarne tło występuje w malarstwie Witkacego stosunkowo rzadko, jeżeli się pojawia, to jako wyraźnie dramatyczny dodatek, np. we wczesnym portrecie „mrocznie” patrzącej na widza Stefanii Jaworskiej (1912), w Ostatnim papierosie skazańca (1924) czy w pastelowym autoportrecie w (czarnym) lustrze (1922).

W portretach pastelowych rysowanych na czarnym tle (jest ich w $\mathrm{Ka}$ talogu prac malarskich kilkanaście ${ }^{134}$ ), spotkać można „ujęcie formy” polegające na modelowaniu twarzy nie przez zamknięty modelunek, lecz przez kolorowe, świetliste kreski szybujące nad czarną przestrzenią twarze te są niezdefiniowane, przeźroczyste, otwarte na nieskończoność. To jakby portrety kosmiczne, rysowane nad Nicością, nie skończone, ledwo zaznaczone kreskami, jak znikające ślady ogników na nocnym niebie meteorytów, tylko na mgnienie oka. „Jak świetliki, które potrzebują ciemności, żeby świecić" - to Schopenhauer. Bungo ma już przeczucie takich portretów, kiedy wyobraża sobie twarz ,jako samoistne ciało niebieskie, lecące wśród międzygwiezdnej przestrzeni" 135 .

Inny sposób przedstawienia Nicości wynika z zasady typów firmy portretowej, ułożonych w szereg wedle podobieństwa i formy od realistycznego do ekspresyjnego. Zaczyna się od wypracowanych, „wylizanych”, by coraz bardziej odchodząc od podobieństwa na rzecz wyrazu i formy, dojść w wypadkach skrajnych do obrazów, w których twarz modela znika pod gąszczem kresek, zmierza do nicości, do zaniku formy. Znowu, jak w filmie, metodą obrazowania jest znikanie i pojawianie się form.

$*$

Ikonografia nicości czerpie $\mathrm{z}$ archiwum obrazów i metafor vanitas. W wersji chrześcijańskiej towarzyszyła jej obietnica pozaziemskiej nagrody w zamian za nic niewarty świat. Bez tego „uprofilowania” repertuar

133 Didaskalia Witkacego są tu niejasne, raz mowa o ukrytych drzwiach pod lustrem, raz pod oknem, co jednak odpowiada wieloznaczności całej tej sceny. Por. J. Degler, Noty do dramatów, [w:] S.I. Witkiewicz, Dramaty, t. I, s. 586.

134 Stanistaw Ignacy Witkiewicz 1885-1939...

135 S.I. Witkiewicz, 622 upadki Bunga..., s. 143. 
„marności nad marnościami”, z którego wywodzi się też Camusowski mit Syzyfa, pasuje również do moralitetu Witkacego. Węzłowisko emocji, pożądania, próżności, to przetłumaczony na ikonograficzną tradycję „taniec śmierci": nim otwiera Witkacy w prologu do Macieja Korbowy serię swoich dramatów. Zamiast Kostuchy z kosą popędzającej tańczących przedstawicieli świata wprowadza Witkacy własny personel Nicości: zmarłych, żyjących dalej wśród żywych i nie bardzo mających gdzie się podziać, skoro „zaświaty nam zabrali”, oraz perwersyjne demony, które kuszą władza i seksem, i zamiast kraść ofiarom duszę, rabują doczesną świadomość. $\mathrm{Na}$ obrazach i rysunkach przyjmuje ten taniec postać „ogólnego zamieszania”, w jakim również dawne demony i diabły mają okazję jeszcze raz odegrać swoje role.

Korowody „potworów”, przewijające się przez całą sztukę Witkacego, nadają tematowi vanitas wymiar próżności w skali dziejowej. Tylko cieniutka warstwa świadomości pokrywa barbarzyństwo, gwałt i animalistyczny seks; spod maski potwora wyłania się postać nowoczesnego „bubka". Jednakże, jak zwykle u Witkacego, u którego motywy obsadzone mogą być w różnych rolach, „potwory” są materiałem sennych, barwnych wizji ze wspomnieniem o utraconym rajskim ogrodzie.

Motyw rozbitego szkła, pękniętej szyby, tak często występujący w holenderskich martwych naturach jako figura zniszczonej całości, symbol przemijalności życia, znak Nicości, pojawia się i w sztuce Witkacego; najbardziej znany przykład to fotograficzny autoportret na rozbitej kliszy. Stefan Okołowicz uznaje tę odbitkę za celową ingerencję Witkacego, a nie za zaakceptowanie przypadku136. Potwierdzają to pastelowe portrety, w których zastosował ten sam motyw: narysowane w manierze trompe l'œil (typowej technice dla obrazów vanitas) resztki stłuczonej szyby w ramie obrazu. Wedle reprodukcji w katalogu takich portretów istnieje kilka, ale może być ich więcej, gdyż charakterystyczna dla Witkacego dwuznaczność formy utrudnia interpretację ${ }^{137}$. Przykładem niewątpliwym jest autoportret $\mathrm{z}$ wiosny 1930 roku. Tylko mały kawałek szkła pozostał u dołu obrazu, częściowo zasłaniając twarz portretowanego widzimy więc nie tylko wizerunek Witkacego, lecz zarazem przedmiot:

136 S. Okołowicz, Metafizyczna dziwność istnienia w fotografiach Stanisława Ignacego Witkiewicza, „Rocznik Historii Sztuki” 2006, t. XXXI, s. 166.

137 Katalog dzieł malarskich: Furia adormentata, 1913, nr I 191; Tomasz Domaniewski, 1924, I 529; portret Edmunda Strażyskiego, 28.5.1928, I 787; Zofia Szumanowa, 10.9.1929, I 1042; Helena Biatynicka-Birula, 12.10.1929, I 1066; Helena Judt $i$ Michat Choromański, 1930, I 1127; autoportret, II/III 1930, I 1174; Maria Baranowa, 28.3.38, I 2121; autoportret jako Mr Hyde, 26/27.4.1938, I 2132 (w kompozycji rysunkowej „niszczonym" materiałem nie jest szkło, ale papier, podłoże, na którym rysunek został wykonany) kompozycja rysunkowa, sierpień 1931, I 1497. 
autoportret pastelowy Witkacego, odłożony, zapomniany, z rozbitą szybą, której kawałek trzyma się jeszcze w ramie.

Ta krucha, przezroczysta granica między bytem a niebytem, nawet jeśli cała, to w każdej chwili może zostać rozbita - „jakaś cienka szybka tylko oddziela mnie od najpotworniejszego strachu. Jak to coś pryśnie, będę wariatem", mówi Kozdroń w W małym dworku138. Kiedy za codziennym obrazem świata dostrzegamy nagle inny, choć niby ten sam, to również szyba jest między nimi. Jeżeli jest czysta, krystaliczna, wtedy widok przez nią wywołuje uczucie metafizyczne, ów dziwny moment dotykający Nicości. „Odczuwał Izydor to, co się działo, jako absolutnie przezroczystą [...] płytę, poprzez którą widział tak samo absolutnie niezmienny krajobraz z wschodniej strony świata, jak i swój własny stan psychiczny"139. Kiedy jest zabrudzona, wtedy patrzy się „w życie i świat jak przez brudną szybę, zza kraty okienka jakiegoś ohydnego klozetu"140. Albo wszystko, co się widzi, zostaje zabarwione przez filtry z odczuć, nastawień, emocji, jak w scenie w Nienasyceniu, w której Genezyp ogląda przez barwny witraż kopulującą parę.

Tajemniczy rysunek przedstawiający „kapliczkę bóstwa Absolutnej Nicości”141 zawiera następujący, zagadkowy tekst: „Architekt Maurycy Petzold pokazał córce Jance i Magowi Jeroboamicie z trudem wykonaną przez siebie Kapliczkę na cześć Bóstwa Absolutnej Nicości. Haarmensch towarzyszący Magowi zaklinał ze łzami w oczach, aby tego (czego?) nie robić, ale na próżno".

Wymienione w tekście postacie stoją po obu stronach kamienistej drogi biegnącej w perspektywie w głąb i dochodzącej do dziwnej konstrukcji przypominającej bramę zbudowaną z dwóch trójkątów. Kaplica Nicości to nie budynek, lecz przejście. Dokładnie tak, jak to opisał Nietzsche w zagadce w Zarathustrze: „Spójrz na tę bramę, karle!... Dwie drogi się tu schodzą, nikt nie przeszedł ich jeszcze do końca. Ta długa ścieżka, co do tyłu wiedzie, czuwa nad wiecznością. A ta, co naprzód prowadzi - to inna wieczność. Te drogi sobie przeczą... a tu, w tej bramie, spotykają się. Nazwa tej bramy jest napisana na górze: "Chwila»". Jak w Witkacowskim uczuciu metafizycznym spotykają się przyszłość i prze-

138 S.I. Witkiewicz, Dramaty, t. II, s. 31.

139 Tenże, Jedyne wyjście, s. 38.

140 Tenże, Pożegnanie jesieni, s. 28

${ }^{141}$ Katalog, I 1649, nr 614, VIII, 1932. Rysunek w zbiorach Muzeum Górnośląskiego w Bytomiu. 
szłość w jednej chwili142. Człowiek jest zaledwie punktem na osi czasu, między przeszłością a przyszłością, „czymś, przez co przepływa prąd istnienia, nie zatrzymując się ani na sekundę"143. W tym miejscu, które jest i którego nie ma, architekt Maurycy Petzold zbudował kapliczkę bóstwa Absolutnej Nicości. Ale czego, wedle komentarza na rysunku, nie powinien był zrobić? Nie pokazywać kapliczki córce? „Nie pozwól mi zobaczyć, kim jestem", czytamy u Schopenhauera ${ }^{144}$.

\section{Metafizyka bez Boga}

[...] chodzi mi o to, żeby stworzyć metafizykę z absolutnym wykluczeniem Boga ${ }^{145}$. [...] zaświat, jeśli jest, jest tylko pewna wariacja tego, co jest tutaj ${ }^{146 .}$ Jedynym naszym zaświatem, tak realnym jak samo życie, jest Sztuka ${ }^{147}$.

U Schopenhauera znalazł Witkacy fundament swojej filozofii. Wyobrażenie woli jako siły sterującej światem jest metaforą otwierającą myślenie - od Freuda po neurofilozofię - o tym, jakich strategii i iluzji używa człowiek, by otoczyć i zabezpieczyć swoje istnienie. Wola to „program”, stan rzeczy, od którego nie ma innej ucieczki, jak kolejne oprogramowania, kolejne nadbudowy, jak pesymizm, nihilizm czy nirwana. Nihilizm, szczególnie ten, który próbuje stworzyć metafizykę bez absolutu, jest, jako nadbudowa, bliski fundamentom.

Witkacy robi porządek w pojęciach, w systemie. Musi to być porządek możliwy do dotknięcia. Pojęcia, jakie powołuje wobec i przeciw Nicości, nie mają w sobie nic tajemniczego. Wręcz przeciwnie, muszą być odczuwalne, dotykalne. To metafizyka oparta na dotyku, dzieje się w granicach monady i z niej wychodzi na zewnątrz, z niej widzi świat oświetlony „latarnią głowną"148. Główne myśli, pojęcia-narzędzia pomocne do tego, by

142 „Siehe diesen Thorweg! Zwerg!... Zwei Wege kommen hier zusammen, die ging noch niemand zu Ende. Diese lange Gasse zurück: die währt eine Ewigkeit. Und jene lange Gasse hinaus - das ist eine andere Ewigkeit. Sie widersprechen sich diese Wege... und hier, an diesem Thorwege, ist es, wo sie zusammen kommen. Der Name des Thorwegs steht oben geschrieben: «Augenblick»". F. Nietzsche, Sämtliche Werke.., t. 4, s. 199 passim (Also sprach Zarathustra).

143 S.I. Witkiewicz, Dramaty, t. I, s. 179.

144 „Lass es mich nicht sehen, wer ich bin”. A. Schopenhauer, Werke, t. I, s. 433.

145 S.I. Witkiewicz, Nieznany traktat filozoficzny Stanisława Ignacego Witkiewicza dedykowany Romanowi Ingardenowi, oprac. B. Michalski, „Pamiętnik Literacki” 2002, r. XCIII, z. 4, s. 217. Por. również komentarz B. Michalskiego do tekstu Witkacego.

146 S.I. Witkiewicz, Dramaty, t. I, s. 198.

147 Tenże, Nowe formy $w$ malarstwie, s. 44.

148 Tenże, Nieznany traktat filozoficzny..., s. 217. 
wyrwać się z kłębu, z choroby na Nicość, krążą wokół ,ja” i w introspekcji szukają podstawy opisu bytu. Świadomość musi wytrzymać brak wieczności i własną ograniczoność w nieskończoności.

A więc zamiast Boga - niemożliwa do zgłębienia Tajemnica Istnienia, obietnica sensu, do którego nigdy się nie dojdzie, ale który gdzieś tam jest. A zamiast wieczności - skupione w jednej chwili uczucie metafizyczne, błysk zaledwie, niemal bez trwania149 (jego odwrotność Witkacy umiejscawia w jakiejś koszmarnej, bezterminowej poczekalni). Chwila nasycona transcendencją, kometa romantyków, przychodzi z nieskończoności i w nieskończoności znika. W tej jednej chwili spotykają się niesamodzielne rzeczy świata: kiedy rozważać je oddzielnie, znikają. Można tylko odczuć ich jednoczesność i wtedy ,ja”, od środka, bezpośrednio, uświadamia sobie swój moment istnienia. W sztuce doświadczyć można tej wieczności w pigułce jako Czystą Formę, w której, jak w epifanii, objawia się złożona całość świata: Jedność w Wielości. Ta formuła bliska magiczności, niemal zaklęcie, żeby się świat nie rozpadł, działa również jako formuła estetyczna, jako skrót na opis i istotę percepcji dzieła sztuki: wszystko łączy w jedno i w jednym widzi wszystko, formalnie, ale zarazem psychofizycznie, gdyż ciało jest pudłem rezonansowym, instrumentem, w którym sztuka gra. Witkacy nie szuka raju, ale spełnienia, intensyfikacji egzystencji. Wartością życia nie jest perspektywa wieczności, lecz chwile świadomości bytu, odczucie siebie w bycie. „Tat tvam asi”, „i ty jesteś tym”, ta znana Schopenhauerowi formuła staroindyjskiej filozofii na zjednoczenie się ze światem wyraża także Witkacowską ideę Jedności w Wielości pojętej w chwili metafizycznego uczucia ${ }^{150}$. Jak ją złapać, zatrzymać, wywołać? Także przez zintensyfikowanie wewnętrznego doświadczenia, przez sztukę. Kiedy nic nie ma - albo kiedy jest tylko nic, sztuka staje się schronieniem i sposobem. Wcześnie, już w czasie pisania Bunga zaczyna rozwijać też teorię sztuki, w której estetyka momentu zastąpi wieczne wartości.

W sztuce - w malarstwie, powieści i w teatrze - nadaje swojemu systemowi postać iście barokowej alegorii Vanitas w równie barokowo skłębionej oprawie. Postaciom na scenie, w powieściach i obrazach nie jest dane wyplątać się z węzłowiska, kotłują się, mordują fizycznie i psychicznie, szukają czegoś, choć nie tam, gdzie trzeba, w innym kierunku, nie zauważając stale obecnej drogi w stale obecnym tle. Ten, kto chce znaleźć wskazówkę, drogowskaz do Tajemnicy Istnienia, musi wprawdzie zajrzeć

149 O znaczeniu chwili w filozofii i w sztuce pisze obszernie Bruno Hillebrand w Ästhetik des Augenblicks.

${ }^{150} \mathrm{O}$ znaczeniu filozofii indyjskiej dla filozofii Schopenhauera zob.: J. Tuczyński, Schopenhauer a Młoda Polska, m.in. s. 217-226.

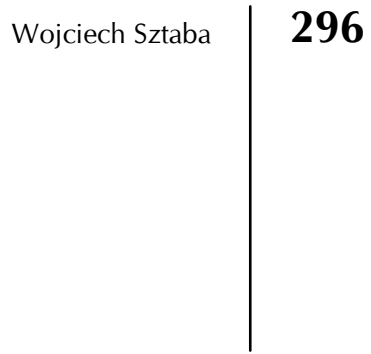


w głąb Nicości, ale nie może być w nią zamieszany. Witkacy - rzecznik przeżycia metafizycznego przez sztukę, objawiającego się $\mathrm{w}$ teatrze w quasi-religijnym doświadczeniu - dał szansę na zrozumienie tylko tym „poszukiwaczom Tajemnicy”, którzy siedzą na widowni. Dla nich uczucie metafizyczne może stać się momentem epifanii; Czysta Forma - jej nieskazitelnym symbolem, symbolem Jedności w Wielości. Zaś udział w teatrze przypominać ma mszę, ceremonię, rytuał - sen. Tak oto spotykają się ze sobą w sztuce myślenie o Nicości i metafizyka bez Boga.

lipiec 2012

Lech Sokół z okazji organizowanej w Warszawie konferencji „Nihilizm i nowoczesność" (październik 2011) zwrócił moją uwagę na problem nihilizmu w twórczości Witkacego - czym zachęcił mnie do napisania tego eseju. 